\title{
Global discovery of bacterial RNA-binding proteins by RNase-sensitive gradient profiles reports a new FinO domain protein
}

\author{
MILAN GEROVAC, ${ }^{1}$ YOUSSEF EL MOUALI, ${ }^{2}$ JOCHEN KUPER, $^{3}$ CAROLINE KISKER, $^{3}$ LARS BAROUIST, $^{2}$ \\ and JÖRG VOGEL ${ }^{1,2}$ \\ ${ }^{1}$ Institute for Molecular Infection Biology (IMIB), University of Würzburg, 97080 Würzburg, Germany \\ ${ }^{2}$ Helmholtz Institute for RNA-based Infection Research (HIRI), 97080 Würzburg, Germany \\ ${ }^{3}$ Rudolf Virchow Center for Integrative and Translational Bioimaging, Institute for Structural Biology, University of Würzburg, 97080 Würzburg, \\ Germany
}

\begin{abstract}
RNA-binding proteins (RBPs) play important roles in bacterial gene expression and physiology but their true number and functional scope remain little understood even in model microbes. To advance global RBP discovery in bacteria, we here establish glycerol gradient sedimentation with RNase treatment and mass spectrometry (GradR). Applied to Salmonella enterica, GradR confirms many known RBPs such as CsrA, Hfq, and ProQ by their RNase-sensitive sedimentation profiles, and discovers the FopA protein as a new member of the emerging family of FinO/ProQ-like RBPs. FopA, encoded on resistance plasmid pCol1B9, primarily targets a small RNA associated with plasmid replication. The target suite of FopA dramatically differs from the related global RBP ProQ, revealing context-dependent selective RNA recognition by FinOdomain RBPs. Numerous other unexpected RNase-induced changes in gradient profiles suggest that cellular RNA helps to organize macromolecular complexes in bacteria. By enabling poly(A)-independent generic RBP discovery, GradR provides an important element in the quest to build a comprehensive catalog of microbial RBPs.
\end{abstract}

Keywords: RNA-binding protein; RNase; FinO/ProO protein; Hfq; CsrA; FopA

\section{INTRODUCTION}

As they do in the other kingdoms of life, RNA-binding proteins (RBPs) play vital roles in many cellular processes in bacteria. Their activities range from enabling basic protein synthesis to facilitating regulatory RNA networks required for bacterial adaptation and genome defence (Holmqvist and Vogel 2018; Babitzke et al. 2019). However, while the collective results of recent global screens have produced nearly saturated RPB catalogs in several model eukaryotes (Hentze et al. 2018), our knowledge about bacterial RBPs has remained patchy, having accumulated largely through studies of individual proteins and serendipitous discoveries. As a result, Escherichia coli has 180 annotated RBPs (Holmqvist and Vogel 2018), and far fewer are known for other bacterial species. At the same time, the surging interest in microbiomes keeps increasing the number of bacteria with relevance to human health (Browne et al. 2016; Lagier et al. 2016). An under-

Corresponding author: joerg.vogel@uni-wuerzburg.de

Article is online at http://www.rnajournal.org/cgi/doi/10.1261/rna. 076992.120. Freely available online through the RNA Open Access option. standing of RNA-centric regulation and the importance of RNA-protein interactions in these many understudied species demands new global approaches to identify bacterial RBPs in a generic manner.

Experimental screens for bacterial RBPs have been hampered by the lack of two important features that have accelerated global RBP discovery in eukaryotes: functional poly(A) tails on transcripts, and efficient incorporation of crosslink-enhancing artificial nucleotides (Bao et al. 2018; Hör et al. 2018). However, there has recently been a surge in poly(A)-independent RBP discovery methods (Smirnov et al. 2016; Asencio et al. 2018; Queiroz et al. 2019; Shchepachev et al. 2019; Trendel et al. 2019; Urdaneta et al. 2019), an example of which is Grad-seq, which predicts new RNA-protein complexes by RNA-seq and mass spectrometry (MS) of cellular lysates after fractionation on glycerol gradients (Smirnov et al. 2016; Hör et al. 2020a, b). Applied to Salmonella enterica serovar Typhimurium (henceforth Salmonella), Grad-seq identified the protein

(C) 2020 Gerovac et al. This article, published in RNA, is available under a Creative Commons License (Attribution-NonCommercial 4.0 International), as described at http://creativecommons.org/licenses/ by-nc/4.0\%. 
ProQ as the third major RBP to be associated with small regulatory RNAs (sRNAs) (Smirnov et al. 2016), after the $\mathrm{Sm}$-like protein $\mathrm{Hfq}$ and the translational repressor CsrA.

ProQ belongs to an emerging class of RBPs whose hallmark is a conserved FinO domain (Chaulk et al. 2011; Attaiech et al. 2016, 2017; Olejniczak and Storz 2017; Holmqvist and Vogel 2018; Babitzke et al. 2019). This RBP is exciting as it binds hundreds of different $E$. coli and Salmonella mRNAs and sRNAs with no obvious consensus sequence (Smirnov et al. 2016; Holmqvist et al. 2018; Melamed et al. 2020), which raises the possibility of FinO domain-mediated global posttranscriptional control via the recognition of a complex structural RNA code (Gonzalez et al. 2017; Holmqvist et al. 2018).

ProQ ranked high in several recent proof-of-concept experiments applying eukaryotic poly(A)-independent RBP enrichment protocols to enteric bacteria. These protocols generally used organic extraction steps or silica-based solid-phase purification to specifically recover RBPs after in vivo UV-crosslinking (Asencio et al. 2018; Queiroz et al. 2019; Shchepachev et al. 2019; Trendel et al. 2019; Urdaneta et al. 2019). Notwithstanding the great potential of these methods, a quick cross-comparison of the published results suggests that each of them has their own bias and dropout rate (Smith et al. 2020). For example, instead of getting enriched, CsrA was depleted upon UV cross-linking in some of these studies (Queiroz et al. 2019; Urdaneta et al. 2019). Thus, additional approaches are needed to unravel the full scope of RBPs in bacteria.

Here, we present such an alternative approach termed GradR, which predicts bacterial RBPs through their changed sedimentation profile in a glycerol gradient when associated RNA partners are removed. We demonstrate proof-of-principle by unveiling the YafB protein of previously unknown function as the third FinO-domain RBP in Salmonella. Like FinO, the founding member of this RBP family (Biesen and Frost 1994), YafB is encoded on a plasmid, and we have renamed it here FopA (Fin $\underline{O}$ domain protein on plasmid/phage A). Intriguingly, the target transcripts of FopA are distinct from both, those of FinO and $\mathrm{ProQ}$, suggesting that the highly conserved FinO domain recognizes very different RNAs despite the fact that all these proteins act in the same cytosolic environment. Furthermore, RNase-treatment causes many other intriguing changes in in-gradient distributions, indicating a much more prominent role of RNA in organizing the cellular proteome of bacteria than currently appreciated.

\section{RESULTS}

\section{Differential sedimentation profiles of RBPs upon prior RNase digestion}

GradR builds on control experiments for Grad-seq (Smirnov et al. 2016), which indicated that if cellular ex- tracts were pretreated with ribonuclease (RNase), this would free proteins of RNA ligands and, in a glycerol gradient, shift RBPs to lighter fractions (Fig. 1A). RBPs will then be identified by comparative mass spectrometry of the treated and untreated gradients, so the theory. As do the conceptually related R-DeeP (Caudron-Herger et al. 2019) and DIF-FRAC (Mallam et al. 2019) approaches for RBP discovery in eukaryotes, GradR works without a UVcrosslinking step.

We first optimized the treatment of bacterial lysates for rapid degradation of RNA while keeping proteolysis to a minimum, settling at nuclease concentrations of $0.3 \mu \mathrm{g} /$ $\mu \mathrm{L}$ RNase $\mathrm{A}$ and $0.8 \mathrm{U} / \mu \mathrm{L}$ RNase T1, and a 20 -min reaction at $20^{\circ} \mathrm{C}$ for a Salmonella lysate of an $A_{260}$ of $\sim 150$.

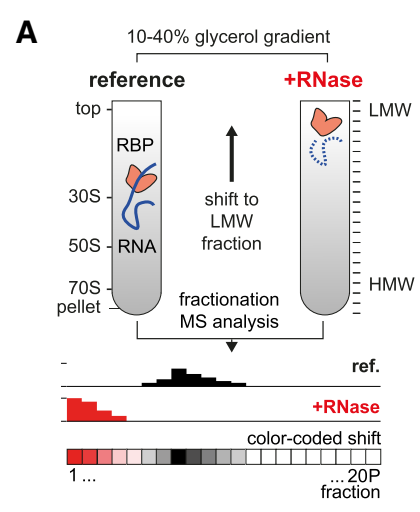

B

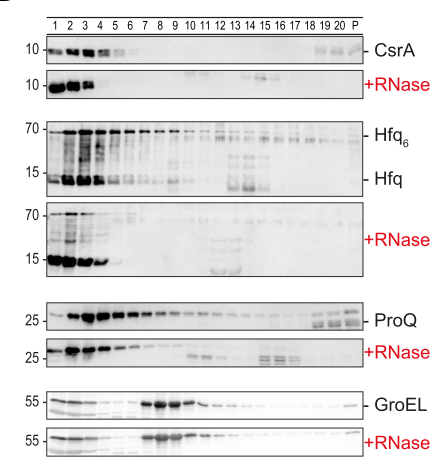

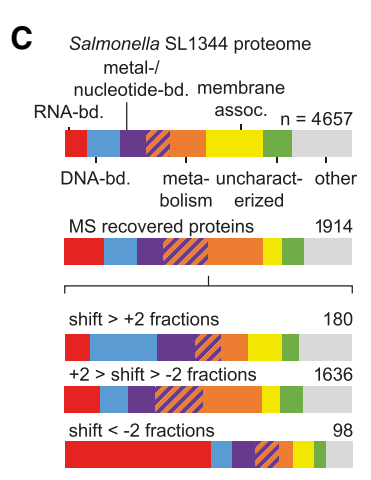

D

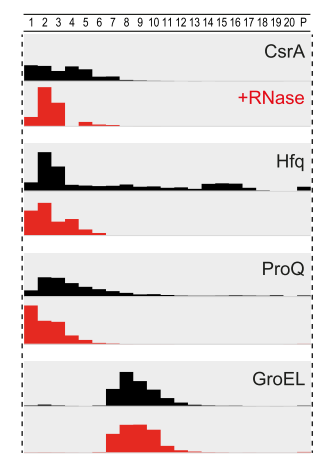

FIGURE 1. RNase-dependent gradient fraction reveals RNA-binding character of proteins. (A) The Salmonella lysate was digested with RNase $A / T 1$, and sedimented in a glycerol gradient that yielded RNA-dependent shifts for RNA-binding proteins (RBPs). The profile shows changes in protein abundance, color-coded from black (shifting from) to red (shifting toward). (B) Sedimentation profile of the global RNA-binding proteins CsrA, Hfq, and ProQ were detected by FLAG-tagged variants and western blotting. After RNase treatment, RBPs shifted to top fractions. The Hfq monomer accumulated after RNase digestion in top fractions. GroEL sedimentation was not affected by RNase treatment. $n=2$. (C) One-third of the Salmonella proteome was recovered by MS. RNA-binding proteins (red) were enriched in the group of proteins with a high relative shift to the top $(<-2$ fractions). $n=2$. (D) The global RBPs correlated well in MS quantification with $B$. Protein abundance was normalized to total protein levels per gradient. Reference and RNase treated sedimentation profiles were represented as black and red bars, respectively. $n=2$. 
Gradients were prepared with $10 \mathrm{mM}$ magnesium concentration in order to ensure $70 \mathrm{~S}$ ribosome integrity and $\mathrm{mRNA}$ comigration with $70 S$ ribosomes or polysomes (Gros et al. 1961; Zitomer and Flaks 1972) in the reference sample. Probing for the model RBPs CsrA, Hfq, and ProQ on western blots, we observed the expected RNase-induced shifts toward low-molecular weight (LMW) fractions (Fig. 1B). In the case of $\mathrm{Hfq}$, the RNase treatment converted most of the hexameric form to monomers that accumulated in early LMW fractions, supporting previous suggestions (Argaman et al. 2012; Panja and Woodson 2012). As expected, the protein chaperone GroEL serving as a negative control did not show an RNase-induced shift.

\section{Global analysis of RNase-treated gradient fractions}

For a global RBP prediction, we determined protein sedimentation profiles by mass spectrometry (MS) across the 20 gradient fractions plus the pellet and compared these profiles between the RNase-treated and untreated reference samples. For normalization, we spiked the gradient fractions with a protein marker prior to digestion and directly proceeded to MS analysis, that is, without precipitation, in order to minimize the risk of losing low-abundance proteins.

Analyzing bacteria in the early stationary phase of growth $\left(\mathrm{OD}_{600}\right.$ of 2$)$, that is, our standard condition in several previous RBP studies (Holmqvist et al. 2016, 2018; Smirnov et al. 2016; Michaux et al. 2017), we detected 2555 Salmonella proteins in the original sample. Sedimentation profiles (gradient samples) were obtained for 2225 proteins (Fig. 1C; Supplemental Table 1), which is similar to the number of detected proteins in a recent RBP discovery study in Salmonella (Urdaneta et al. 2019). We observed a good correlation of overall protein abundance between the two gradients (Supplemental Figs. S1 and S2A,B), arguing that there would be few false positives resulting from potential RNase-induced protein insolubility. Permitting a less than or equal to fivefold difference in protein intensity-based absolute quantitation (iBAQ [Schwanhäusser et al. 2011]) between the treated and untreated gradient, we proceeded with 1914 proteins (Supplemental Fig. S2B), which covered $\sim 75 \%$ of the detectable Salmonella proteome and showed an expected enrichment of cytosolic localization (Fig. 1C). Importantly, the 98 proteins with clear RNase-induced shifts toward lighter fractions were strongly enriched in annotated RBPs including ribosomal proteins (Fig. 1C). Moreover, the MS data matched well the western blot profiles of individual proteins, for example, CsrA, Hfq, ProQ, and GroEL (Fig. 1D), suggesting that the global proteomics-based GradR approach could be used to discover new RBPs.

Not all known RPBs shifted fractions upon RNase treatment (Fig 1C; Supplemental Fig. S2C-E). Obvious false negatives include the cold shock-like proteins CspA,
CspC, CspE, and CspB (a.k.a. CspJ), which shifted only marginally (Supplemental Fig. S2E) despite the fact that each of them binds hundreds of different cellular transcripts (Michaux et al. 2017). These RBPs are difficult to assess; with the present glycerol concentration they are LMW to begin with (Supplemental Fig. S2E). Regarding false positives, proteins might shift in the gradient not because they themselves loose an RNA ligand but because they are in a complex with a bona fide RBP.

\section{Classification and visualization of RNase-induced changes}

To classify RNase-dependent sedimentation profiles of proteins, we used two different descriptors: the number of fractions shifted, and the change in general presence and distribution in the gradient. We consider the latter as a rough indicator of the extent of a protein's interactions with cellular transcripts which themselves vary greatly in length (thus, molecular weight) and shape. The result is a map with four quadrants (Fig. 2).

Quadrant I at the top left was enriched with well-established RBPs; for example, CsrA, Hfq, and ProQ. In general, the proteins in this quadrant each spread over several neighboring fractions but their peak both sharpens and shifts toward lighter fractions upon removal of their RNA partners. We will describe further below how this quadrant unveiled a new FinO-domain RBP, but before this discuss several intriguing patterns in the other three quadrants, which represent opposing and more complex scenarios (Fig. 2).

\section{Sedimentation profiles of many Salmonella proteins are sensitive to RNase treatment}

Quadrant II is dominated by r-proteins of the ribosome (Fig. 2), which is the largest known ribonucleoprotein particle (RNP) in Salmonella (Smirnov et al. 2016; Burley et al. 2018). 70 S ribosomes typically sediment in high molecular weight (HMW) fractions $19-20$ as well as the pellet (Supplemental Figs. S1A,B, S2C), but as RNase fragments ribosomal RNA, the 70S RNP decomposes and subcomplexes appear (Supplemental Fig. S1B). Concomitantly, r-proteins of the small (30S) and large (50S) subunits appear in LMW fractions and tend to spread over more fractions, that is, increase in distribution (Fig. 3A).

In quadrant III, we note several proteins that normally occur in LMW fractions (in line with their molecular weight), but after RNase treatment show shift to larger complexes in HMW fractions and concomitantly broader distribution (Figs. 2, 3A). These include several ribosome-associated factors such as the $16 \mathrm{~S}$ rRNA methyltransferase KsgA and the 50S GTPase ObgE, which upon RNase-treatment occupied the $30 \mathrm{~S}$ or $50 \mathrm{~S}$ fractions, respectively. KsgA and ObgE have been observed in cryo-EM reconstruction to interact with $30 \mathrm{~S}$ and $50 \mathrm{~S}$ ribosomes, respectively 


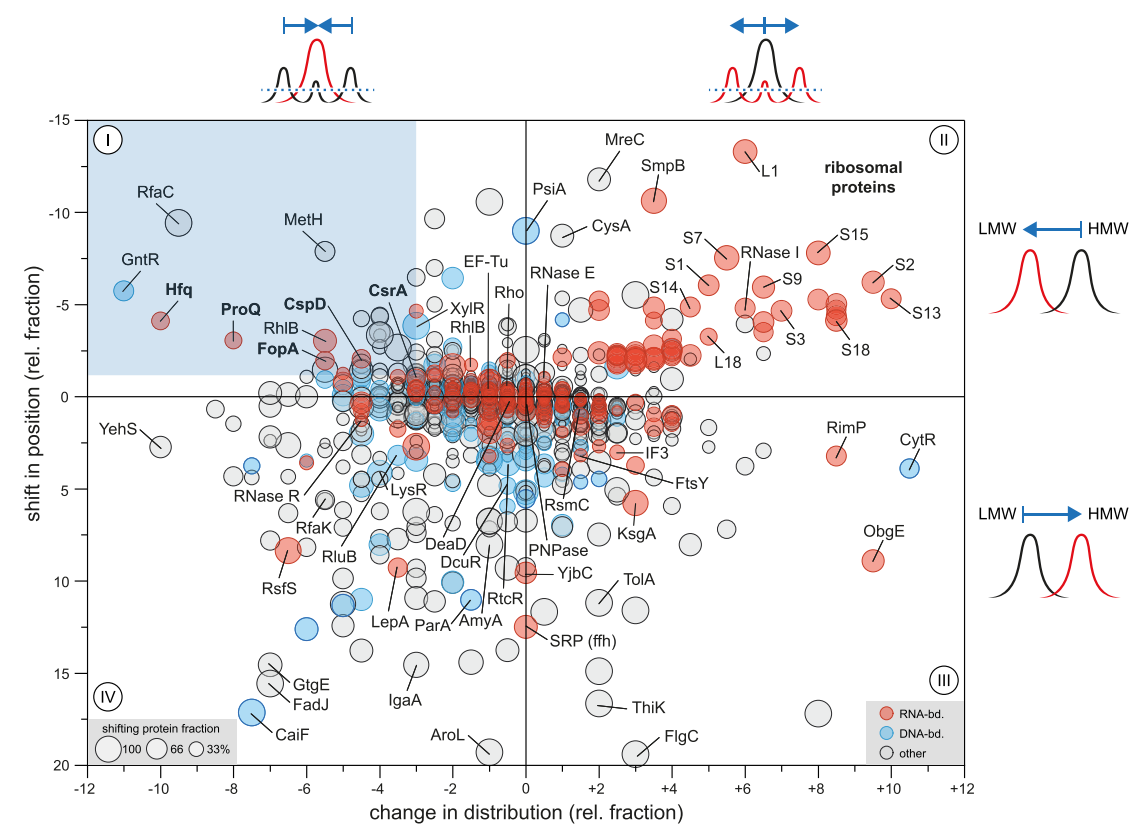

FIGURE 2. RBPs shift and reduce distribution in the gradient. In addition to a shift to LMW fractions, the presence and distribution of $\mathrm{Hfq}, \mathrm{ProQ}, \mathrm{CspD}$, and $\mathrm{CsrA}$ were reduced in the gradient upon RNase treatment (quadrant I). Ribosomal proteins increased distribution in the gradient while still shifting to LMW fractions (II). Some proteins shifted to HMW fractions upon RNase treatment or pelleted (III, IV).

(Boehringer et al. 2012; Feng et al. 2014), and both were predicted to interact with rRNA in these structures. Many other proteins show similar behavior (Supplemental Fig. S3), and these may be candidates for presently unrecognized functions in protein synthesis.

Quadrant IV represents proteins that shift to HMW fractions and become less spread upon RNase treatment; most of them end up in the pellet, which could mean either association with very large complexes (e.g., 70S) or simply, insolubility (Fig. 3A). The signal recognition particle (SRP), composed of protein Ffh and 4.5S RNA, stalls translating ribosomes until their recruitment by receptor FtsY to the membrane for cotranslational translocation of the protein to be synthesized (Walter et al. 1981; Halic et al. 2004). The Ffh protein shifted almost completely to the pellet as its 4.5S RNA partner was digested. In contrast, several proteins did not pellet but appeared to associate with RNA polymerase (RNAP), as discussed in the next section, or appeared in other HMW fractions. For example, ribosome silencing factor RsfS shifted to 50 S subunit fractions 15-17, which would be in line with its described molecular function as an anti-association factor (Li et al. 2015) that targets the large ribosomal subunit during starvation (Fig. 3A).

\section{RNase induces shifts of proteins into and out of RNAP fractions}

The RNA polymerase (RNAP) is a $450-k D a$ complex comprised of the $\alpha / \beta / \beta^{\prime} / \omega$ (RpoA/B/C/Z) subunits, and $\sigma$ factors that control promoter binding. In addition, RNAP is an RNP when in complex with 6S RNA (Wassarman and Storz 2000). While RNAP itself did not shift upon RNase treatment, several transcription factors (TFs) changed distribution (Fig. 3B). One striking example is the TF RtcR, which together with $\sigma^{54}$ controls transcription of the RNA repair system RtcAB (Genschik et al. 1998). RtcR sedimented in the same fractions (4-6) as did its own mRNA (Smirnov et al. 2016); these fractions partly overlap with RNAP. Yet, RNase treatment shifted RtcR to HMW fractions 7-9 (Fig. 3B). It is tempting to speculate that binding to its own mRNA modulates the interaction of RtcR with RNAP, and more generally, that RNA-dependent associations with RNAP could provide specific feedback mechanisms in transcriptional regulons (see discussion in Holmqvist and Vogel 2018).

Another prominent RNase-induced shift toward RNAP fractions is seen with $\mathrm{SmpB}$, the protein in the tmRNA-containing RNP that rescues stalled ribosomes (Rae et al. 2019). Interestingly, tmRNA was previously observed to partially sediment in the RNAP fractions as well (Smirnov et al. 2016), indicating a potential link between translation and transcription of tmRNA (Fig. 3C).

\section{A candidate FinO-domain RBP}

Quadrant I (Fig. 2) represents profiles most expected for a typical RBP, that is, RNase treatment would induce a shift toward LMW fractions and cause a more compact distribution in the gradient. After hierarchical clustering of sedimentation profile changes, we obtained two main clusters of proteins with RNase-driven enrichment in either fraction 1 or fraction 3 (red, blue, respectively, constrains: shift $<-1$, change in distribution $<-3$, shifting protein fraction $>40 \%$, Fig. 4A). The former cluster contained not only CspD, Hfq, and ProQ, but also the FopA protein of unknown function. As per the global MS data, FopA primarily sedimented in fractions 2-3, but shifted to fractions 1-2 upon RNase treatment (Fig. 4B). Western blot analysis using a Salmonella strain in which we had fused a carboxyterminal $3 \times F L A G$ tag to the fopA gene confirmed this prediction (Fig. 4C), and made FopA an attractive candidate for a previously unrecognized RBP.

FopA is encoded on the resistance plasmid pCol1B9 (a.k.a. P2 of incompatibility group Incl $\alpha$, GenBank: HE654725.1), which is one of three plasmids in the 


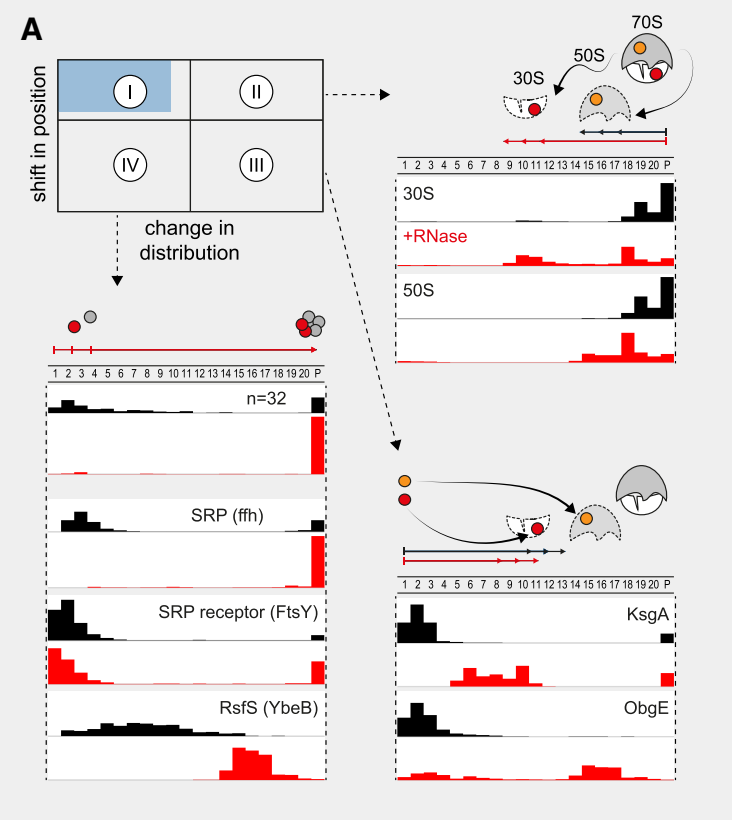

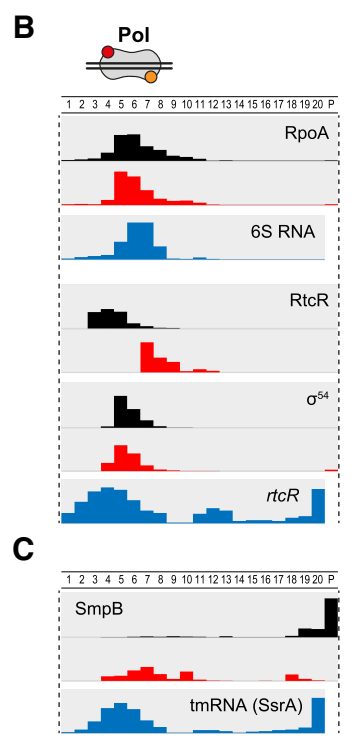

FIGURE 3. Complex scenarios are possible for ribosome or polymerase associated proteins. (A) Map from Figure 2 indicating locations of protein candidates in further panels. In quadrant II, $70 \mathrm{~S}$ ribosomes disintegrated and proteins shifted toward the LMW fractions corresponding to $30 \mathrm{~S}$ and $50 \mathrm{~S}$ fractions, increasing the distribution in the gradient. In quadrant III, translation factors occupied subunit fractions, shifting from LMW fractions to ribosomal fractions. In quadrant IV, a number of factors pelleted upon RNase treatment that may require RNA for integrity. An interesting example was the SRP protein, but also some transcription and translation factors were shifted to HMW fractions. (B) The RNAP complex did not shift. RNAP proteins correlated with 6S RNA (RNA sedimentation profiles are represented as blue bars) (Smirnov et al. 2016). The $\sigma \mathrm{S}$ factor shifted to LMW fractions. Interestingly, transcription factors shifted between polymerase-associated fractions; for example, RtcR that was allocated before RNase treatment closely to rtcR RNA (Smirnov et al. 2016). (C) The trans-translation factor SmpB shifted to polymerase associated fractions after RNase treatment, and partly overlapped with its associated tmRNA (Smirnov et al. 2016).

S. enterica strain SL1344 used here (Fig. 4D; Asano et al. 1999). pCol1B9 expresses colicin lb, a narrow-spectrum bacteriocin against Enterobacteriaceae. The fopA gene lies between yafA and yagA; all of these genes encode proteins of unknown function. Intriguingly, according to a recent update of the Pfam database (El-Gebali et al. 2018), FopA carries a FinO domain (entry: PF04352, Fig. 4E), making it the third such protein in Salmonella, in addition to FinO from the conjugative transfer locus on plasmid pSLT, and ProQ from the chromosome. Moreover, FopA possesses the conserved FinO domain residues Arg157 and Tyr146, which are essential for RNA binding by ProO (Pandey et al. 2020), and key residues in a homology model of FopA (Fig. 4F). Apart from that, FopA represents a distinct branch of FinO-domain proteins (Fig. 4G), with plasmid or chromosome encoded homologs in Escherichia, Shigella, and Klebsiella. Specifically, FopA lacks the amino-terminal domain of FinO and the carboxy-terminal domain of ProQ but exhibits a distinct amino-terminal domain with two stretches of positively charged residues.
Available RNA-seq data (Canals et al. 2019) predict differential expression of fopA under specific conditions. In western blot analysis, FopA accumulated in stationary phase (OD600 of $2+6 \mathrm{~h}$ ), but also in media that induce the Salmonella pathogenicity island 2 (SPI-2) (Fig. 4H). By semi-quantitative comparison with ProQ for which a copy number of 600-1200 monomers per E. coli cell has been determined (Supplemental Fig. S4A; Wiśniewski and Rakus 2014; Soufi et al. 2015), we infer that FopA is present in 200-400 copies per Salmonella cell (stationary phase). In other words, FopA is an abundant candidate RBP with an intracellular concentration in the micromolar range.

\section{FopA is a plasmid-encoded RBP with a unique target suite}

To test RBP activity of FopA and identify potential RNA ligands in vivo, we performed a RIP-seq analysis (Chao et al. 2012), sequencing transcripts after coimmunoprecipitation (colP) with the tagged protein in the fopA:: $3 \times-$ FLAG strain grown to early stationary phase. Comparison with previous RIP-seq results for ProQ obtained in the same growth phase (Smirnov et al. 2016) yielded two key observations. First, despite their sharing a FinO domain, FopA and ProO have very different target suites (Fig. 5A). Reads obtained with FopA are dominated by Inc (Fig. 5A-C), which is a $\sim 70$-nt regulatory RNA expressed from the same plasmid that encodes FopA. In contrast, Inc is hardly recovered in RIP-seq of ProQ (Smirnov et al. 2016) (reanalyzed in Fig. 5A).

Second, although their targets are distinct in primary sequence, FopA and ProO both associate with highly structured transcripts (Fig. 5B). Interestingly, Inc and STnc700 both end with a $4 \mathrm{U}$ stretch, the latter of which is a recently proposed $3^{\prime}$ end-located recognition element for binding by the FinO-domain (Stein et al. 2020). As previously observed with ProO (Holmqvist et al. 2018), the targets of FopA share no obvious primary sequence or structural motif as none could be predicated that fits all the main targets (Supplemental Fig. S4B), hence we conclude that FopA binds structured RNAs by a hidden code.

Inc is a cis-antisense RNA in the $5^{\prime}$ region of repZ encoding the replication initiator protein of pCol1B9 (Asano et al. 
A

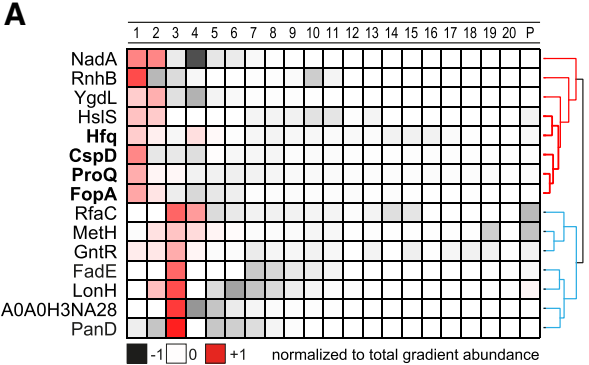

D

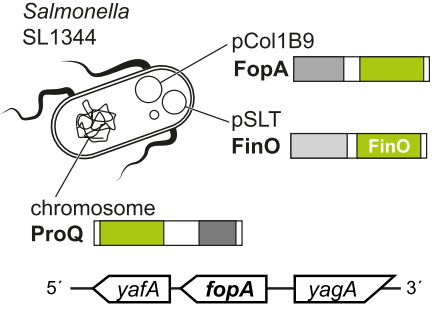

E

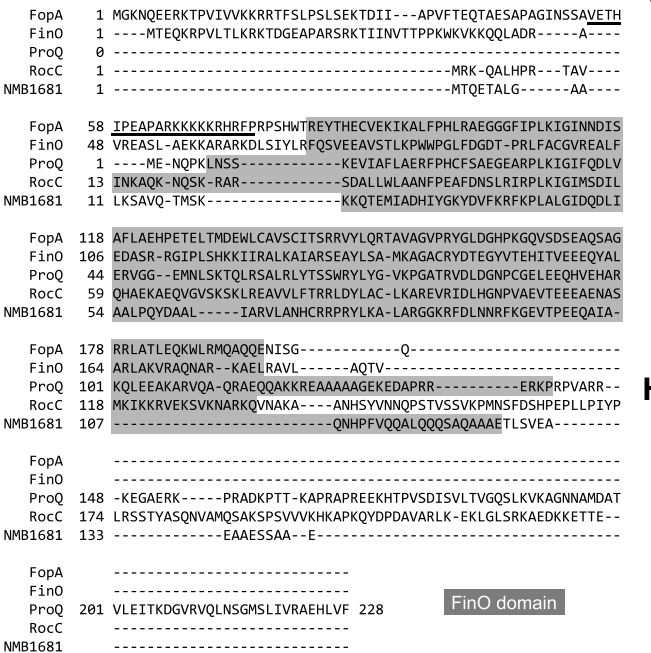

B

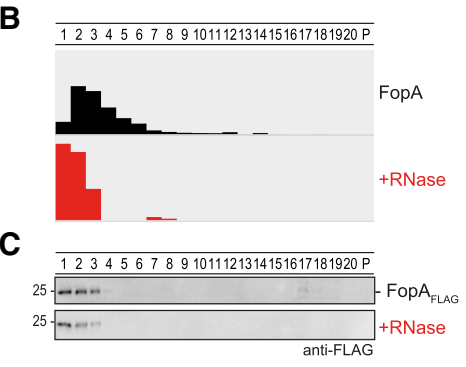

$\mathbf{F}$

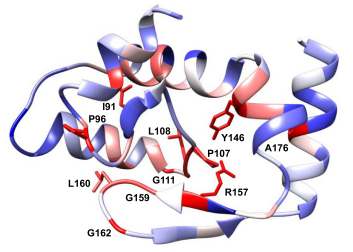

G

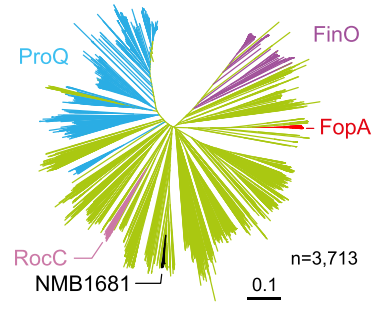

H

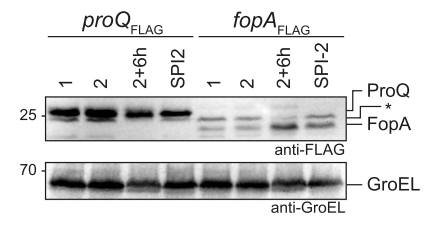

FIGURE 4. The FinO-domain protein FopA is abundant with a unique amino-terminal domain. (A) Hierarchical clustering of candidates that shifted to LMW and reduced distribution (Fig. 2, blue box, filtered to $>40 \%$ shifting protein fraction) resulted in clustering of $\mathrm{Hfq}$, ProO, CspD, and the RBP candidate FopA in the red cluster. In the blue cluster, proteins shifted toward fraction 3. (B) The MS quantification of FopA showed a similar sedimentation shift as for ProQ, which was confirmed by western blot analysis $(C)$. (D) Salmonella harbors three FinO-domain proteins. ProQ is encoded on the chromosome whereas FinO and FopA are encoded on plasmids. (E) FopA homologs show a unique amino-terminal domain that is different to the FinO amino-terminal domain. The central FinO domain in FopA (PF04352, gray background) shows conserved key residues. $(F)$ Homology model of the FinO domain of FopA with color-coded conservation (red indicates high conservation). (G) FopA proteins represent a distinct branch (red) in a phylogenetic analysis based on protein sequences of 2569 FinO-domain containing proteins (PF04352, Pfam 32.0, Clustal Omega analysis). (H) FopA levels are strongly elevated at late stationary phase and increased in SPI-2-inducing conditions. (*) Anti-body cross-reaction.

1998). The low-abundance repZ mRNA is also enriched by colP with FopA (Fig. 5C). Interestingly, Inc/repZ and FopA show equal phylogenetic distribution, indicating functional linkage (Supplemental Fig. S4C). While Inc and repZ are plasmid-encoded transcripts, other top targets of FopA are transcribed from the Salmonella chromosome. These latter targets include STnc1590, which is a cis-antisense RNA to STnc1580 (found in several different enterobacteria); the noncoding RNA STnc700 from the leader region of the histidine operon mRNA; and the transcribed mgtM region that is important for ATP-sensing and regulation of the mgtCBR operon (Lee and Groisman 2012). Interestingly, the $\mathrm{mgtCBR}$ operon is also regulated by ProQ (Westermann et al. 2019). In summary, FopA is the third FinOdomain protein of Salmonella, with targets in both a plasmid and the core genome of this bacterium.

\section{FopA accelerates RNA duplex formation}

Seeking to confirm the predicted RBP activity of FopA, we selected the IncrepZ RNA pair for in vitro binding experiments. These two RNAs form a kissing complex that subsequently progresses to a four-way junction (for review, see Kolb et al. 2001). For our binding experiments, we purified recombinant Salmonella FopA protein after expression in E. coli and rendered it RNA-free by ion-exchange chromatography, thus reaching a purity of more than 95\% (Fig. 6A; Supplemental Fig. S5).

Using electrophoretic mobility shift assays (EMSA), we determined an apparent affinity constant of $\sim 1 \mu \mathrm{M}$ for FopA and Inc RNA (Fig. 6), which is a good fit with both the intracellular concentration of FopA and reported affinities of other FinO-domain proteins (Attaiech et al. 2016; Smirnov et al. 2016; Holmqvist et al. 2018; Bauriedl et al. 2020). FopA displayed similar affinities for the repZ 5'UTR fragment fully antisense to Inc or for a preformed Inc-repZ RNA complex (Fig. 6B). Since FopA bound Inc and repZ both individually and as a complex, we also assessed whether it affects the kinetics of Inc-repZ complex formation. Once formed, the Inc-repZ complex has no apparent off-rate, hence the initial association rate is equivalent to its formation rate $\left(k_{2}\right.$, as previously established for Inc and orthogonal systems [Persson et al. 1988; Tomizawa 1990; Asano et al. 1998]). 
A
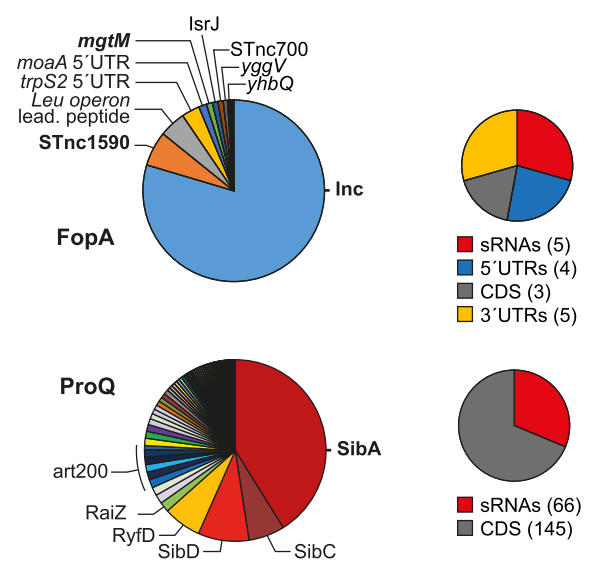

B

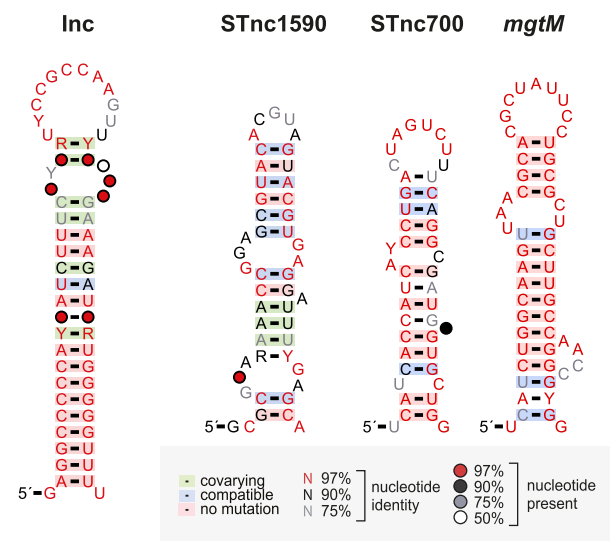

C

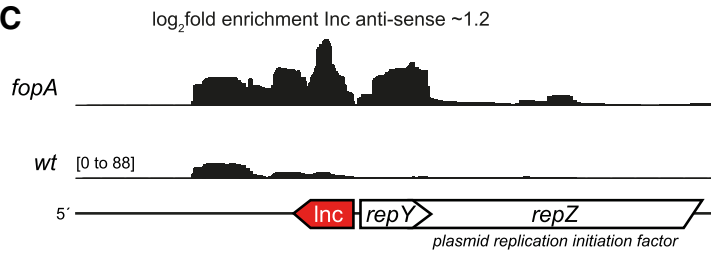

wt $[-35,305,520$ to $-0,05]$

fopA

$\log _{2}$ fold enrichment Inc $\sim 4.9$

FIGURE 5. FopA is a global RBP that targets structured RNAs. (A) The major targeted RNA was the antisense RNA Inc, followed by STnc1590, mgtM, and STnc700 ( $\log _{2}$-fold change $>4, n=17$ ). The RNA targetome of FopA was very different to ProQ recovered RNAs that were reanalyzed differently from Smirnov et al. (2016). (B) FopA targeted RNAs were analyzed for conservation motifs by the CMfinder algorithm. Homologs were searched by GLASSgo (1.5.0, Freiburg RNA tools [Lott et al. 2018]). The CMfinder algorithm determined RNA motifs (0.4.1.18 [Yao et al. 2005]), and R2R was used for visualization (1.0.6 [Weinberg and Breaker 2011]). (C) FopA-colP read-coverage of the repZ locus. Inc is heavily enriched, together with the sparsely expressed repZ mRNA.

Importantly, FopA accelerated complex formation of the Inc and repZ RNAs by approximately sevenfold (Fig. 6C). As such, the primary function of FopA may be that of an
RNA chaperone, similar to the molecular function of its plasmid-encoded sibling FinO in the FinP-traJ conjugation control system (Arthur et al. 2003).

To map FopA binding sites within Inc, we performed RNA structure probing with the single-strand specific endoribonucleases, RNase A (cuts between unpaired pyrimidines) and RNase T1 (cuts at unpaired guanosines). As shown in Figure 6D, FopA protected Inc from cleavage in the loop region at $\mathrm{G}_{46}$, and in general, protected Inc from complete degradation by RNase A. In the Inc-repZ complex, the interbridged region was protected between $U_{34}-U_{37}$ and at $A_{57}$. Concurrently, Inc was deprotected at positions $U_{53}, C_{54}$, and $U_{56}$, indicating an effect on the RNA structure at the cross-junction point. Taken together, by showing binding of FopA to its major RNA ligands in vitro, we established proof-of-principle that GradR can predict a previously unrecognized bacterial RBP.

\section{DISCUSSION}

GradR is conceptually related to two recently published approaches for eukaryotes, R-DeeP and DIF-FRAC, which used sucrose instead of glycerol gradients (CaudronHerger et al. 2019) or size-exclusion chromatography (Mallam et al. 2019). Together, these two latter studies predicted >1400 so-called RNA-dependent proteins or complexes in human cells; in other words, $>7 \%$ of the human proteome would be sensitive to RNase treatment, which is in the same range as the $>5.5 \%$ predicted here for a bacterial proteome. In order to visualize these RNase sensitivities and evaluate individual proteins in the context of their physiological role and published literature, we provide an interactive browser (Fig. 7, www.helmholtz-hiri.de/en/ datasets/GradRSeT) that also allows one to quickly compare proteins from related organisms via Pfam protein domain annotations (El-Gebali et al. 2018).

There has been a flurry of new approaches using organic extraction or silica-based purification to globally predict RBPs, several of which also established proof-of-principle for usability beyond eukaryotes with E. coli or Salmonella (Queiroz et al. 2019; Shchepachev et al. 2019; Urdaneta et al. 2019). We cross-compared our Salmonella GradR data set with the list of Salmonella RBP candidates predicted by Phenol Toluol extraction (PTex [Urdaneta et al. 2019]). PTex predicted 172 RBP candidates, of which 29 had an annotated GO-term "RNA-binding" representing $\sim 21 \%$ of all Salmonella proteins within that GO term. For comparison, GradR detects 210 RNase-sensitive proteins, 34 of which ( $25 \%$ ) have the GO term "RNA binding." Interestingly, the GradR and PTex predictions share only 24 RBP candidates, 62\% of which are established RBPs (Supplemental Fig. S6A). As far as cross-comparison of Salmonella with E. coli data permits, we correlated GradR with silica-based recovery of UV-crosslinked RBP candidates to RNA by TRAPP (Shchepachev et al. 2019). 
A

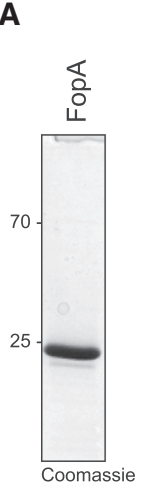

B

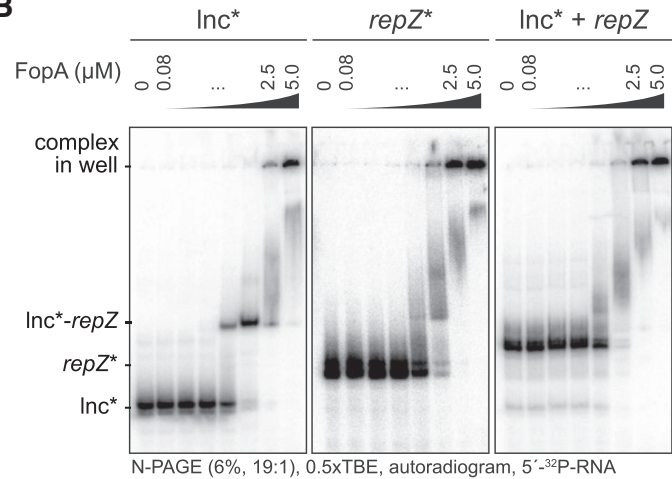

D

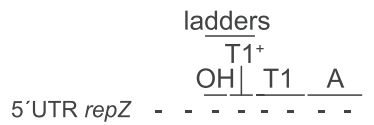

FopA $(5 \mu \mathrm{M})-+\ldots+\cdots$

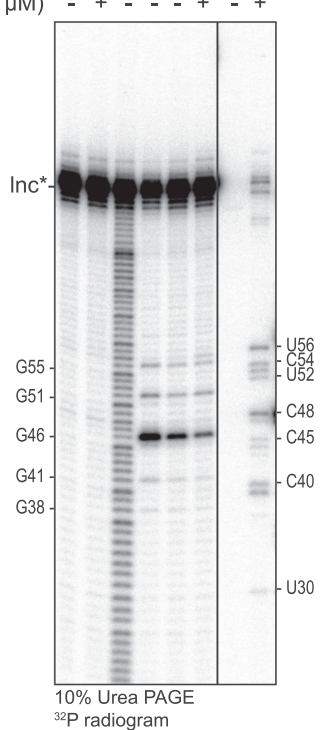

C
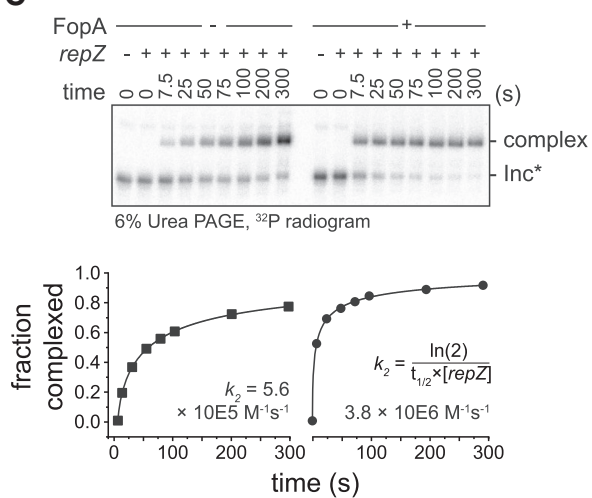

FIGURE 6. FopA protects Inc and anneals it to the 5'UTR of repZ. (A) Purified FopA with cleaved-off tag. (B) FopA bound Inc, repZ, and the IncrepZ complex with an apparent $K_{D}$ about $1 \mu \mathrm{M} . n=2$. (C) FopA accelerated Inc*-repZ complex formation. $k_{2}$ represents the rate constant. $n=2$. (D) FopA protected full-length Inc alone and in the complex with repZ from RNase A degradation at loop regions. $n=2$.

Of the 377 candidates from TRAPP, GradR found 42; again, most (67\%) of these shared proteins are established RBPs (Supplemental Fig. S6B). It is possible that the crosslinking step used in these other methods (Asencio et al. 2018; Queiroz et al. 2019; Shchepachev et al. 2019; Trendel et al. 2019; Urdaneta et al. 2019) helps to enrich weakly interacting candidates. In contrast, GradR requires RNPs to remain stable after lysate preparation. Therefore, we consider GradR as an orthogonal RBP discovery method to UV-crosslinking based approaches. Most importantly, its generic nature provides an experimental route to glance at the major RBPs of any microbe of interest, which becomes important in light of the thousands of understudied bacteria now known to populate the human body.

Salmonella being a well-characterized pathogen, potential RBPs among its virulence factors are of special interest. While previous RNA-binding domain based searches failed to predict RBPs among Salmonella's secreted virulence factors (Sharan et al. 2017; Tawk et al. 2017), we note that the virulence-associated protein YopD of the related pathogen Yersinia pestis is well-known to moonlight as an RBP (Chen and Anderson 2011). In addition, Listeria monocytogenes has just been shown to secret an RBP to manipulate infected host cells (Gerovac and Vogel 2019; Pagliuso et al. 2019). Interrogating RNase sensitivity of Salmonella virulence-associated proteins (Supplemental Fig. S7A), we observe pronounced shifts toward central fractions for the invasion protein InvF, the secretion system apparatus protein PrgJ, and the protein encoded by orf319. The invasion protein OrgB, the bacteriophage-encoded virulence factor GtgE, effector protein SseK1, and an uncharacterized prophage-encoded 


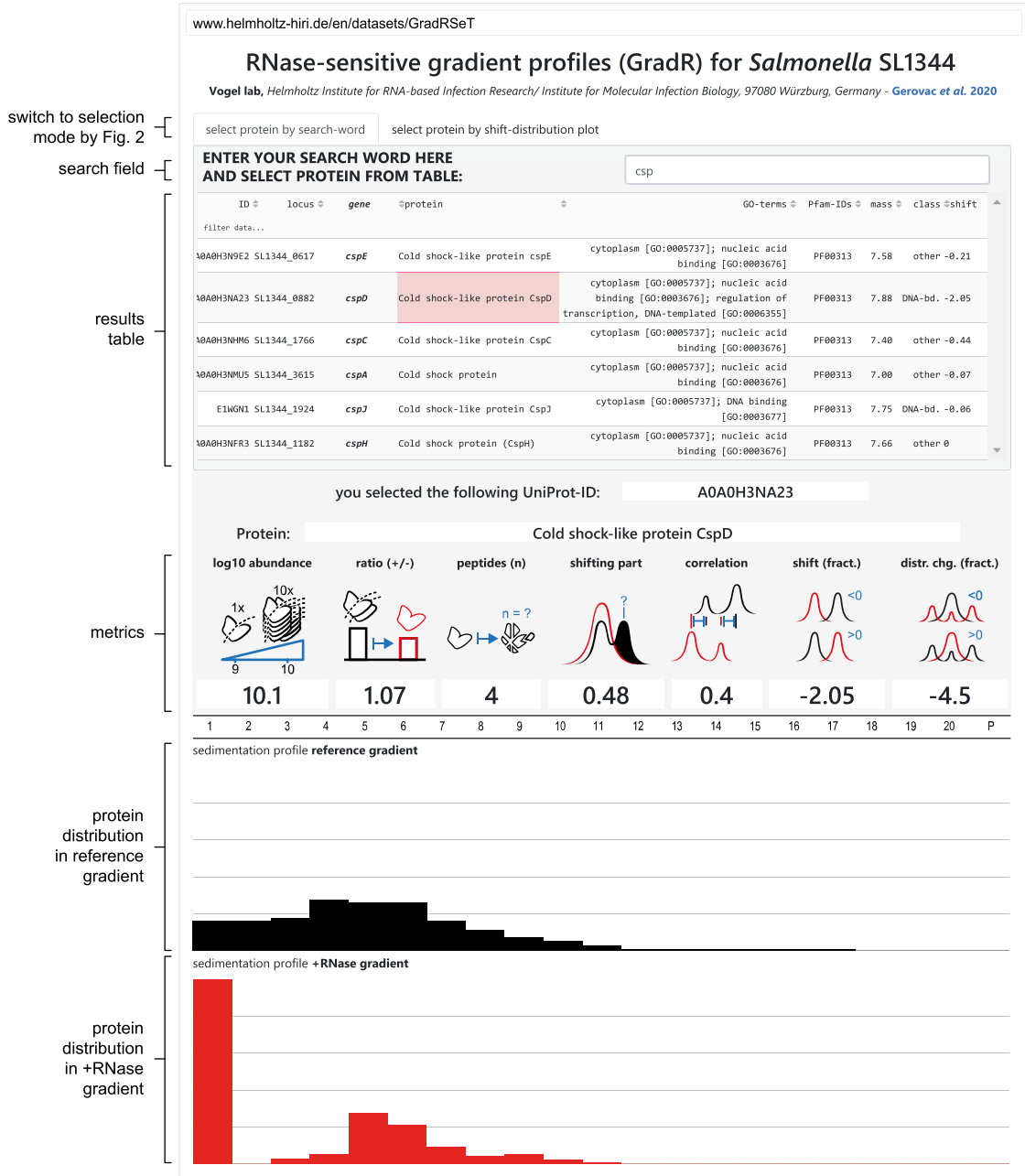

FIGURE 7. Visualizing sedimentation patterns and RNase sensitivity data. Complex GradR data can be visualized and explored in a browser, available at www.helmholtz-hiri.de/en/ datasets/GradRSeT.

NTPase (SL1344_2214) pelleted upon RNase treatment. Hypothetical virulence protein MsgA, sedimenting in fractions 1-3, shifted to fraction 1 upon RNase treatment, making it a good RBP candidate. Importantly, GradR might find even more potential RBPs when Salmonella is grown under conditions that fully induce its virulence genes, so more proteins accumulate to levels that permit detection by MS.

Other classes of proteins lend themselves for inspection in GradR data. For example, studies in eukaryotes have accumulated evidence that many enzymes from intermediary metabolism may moonlight as RBPs, often by binding their own mRNAs (Hentze et al. 2018). Of studies in bacteria, one in E. coli proposed 1000 RBP candidates that comprised mainly metabolic proteins (Shchepachev et al. 2019). A primary example of a metabolic RBP in E. coli is the iron-sensing protein Aconitase B. This enzyme acts in the tricarboxylic acid (TCA) cycle and directly stabilizes its own mRNA (acnB) when intracellular iron becomes scarce (Benjamin and Massé 2014). Here, the $93.5 \mathrm{kDa}$
AcnB protein is present in fraction 3 in a single peak that is unaffected by RNase treatment (Supplemental Fig. $\mathrm{S} 7 \mathrm{~B}, \mathrm{C})$. Potential reasons for failure to detect this established RBP by GradR include the use of iron-rich media in our study, and a possible instability of the AcnB-mRNA complex in lysate. However, we do observe shifts upon RNase treatment such that several metabolic proteins move to HMW fractions (AraA, AmyA, CbiK, $\mathrm{RfaG}$ ) or the pellet (RfaK, NarG, FrdB, CyoB, FadJ, AroL), which may indicate that certain metabolic enzymes require intracellular association with RNA for integrity.

The power of GradR is well illustrated by its ability to validate not only all three sRNA-related RBPs (CsrA, Hfq, and ProQ) of Salmonella but also to predict a new FinO-domain RBP from a plasmid, that is, a common type of extrachromosomal element for which there has been almost no systematic annotation effort (Pilla and Tang 2018). FinO-domain proteins are a growing class of RBPs that target structured RNA molecules in the cell, distinct from tRNA and rRNA (Attaiech et al. 2016; Smirnov et al. 2016; Holmqvist et al. 2018; Bauriedl et al. 2020; Melamed et al. 2020). While most of the recent attention to this RBP class has been on global posttranscriptional regulation by the chromosomally encoded ProQ and RocC proteins, the founding member of this class (the FinO protein) is encoded on a plasmid (Timmis et al. 1978), just as is FopA. FinO's assumed main cellular RNA targets (the FinP sRNA-traJ mRNA pair) are also plasmid-encoded (Mark Glover et al. 2015), as is FopA's main target, the Inc RNA. In contrast, ProQ stably associates with transcripts from the chromosome. Nonetheless, all these RBPs select their very different targets from the same pool of cytoplasmic transcripts, with the same type of FinO domain. Importantly, since the Salmonella virulence plasmid pSLT encodes a homolog of E. coli FinO (Fig. 4D), our work establishes this bacterium to express all three such RBPs (FinO, ProQ, FopA). Salmonella could thus be a test bed for domain swapping experiments to address what intramolecular or cellular factors, including intracellular localization, determine target selection. In addition, the RNA interaction by ligation (RIL)-seq technique (Melamed et al. 2016), which in E. coli revealed diverse overlapping, complementary, or competing roles for ProO and $\mathrm{Hfq}$ 
(Melamed et al. 2020), may offer a more sensitive tool than colP to study currently unknown RNA interactions among the target suites of these three FinO domain RBPs.

Progress on defining its RNA interface notwithstanding (Ghetu et al. 2000, 2002; Arthur et al. 2011; Attaiech et al. 2016; Immer et al. 2018; Pandey et al. 2020), the structure of a FinO domain with a bound RNA remains to be solved. The $22 \mathrm{kDa}$ FopA protein can be purified to homogeneity (Fig. 6A) and its RNA ligands offer tight folds, both of which is conducive to structural studies. Given FopA's distinct sequence (Fig. 4E,G), we expect a structurally resolved FopA-RNA complex to provide important complementary information in the quest for the rules that govern the intriguing selectivity of the FinO domain for RNA structure.

\section{MATERIALS AND METHODS}

\section{Cell lysis, RNase digestion, and gradient fractionation}

Salmonella SL1344 cells were grown in Lysogeny broth (LB) media to transition phase at $\mathrm{OD}_{600}$ of 2.0, pelleted at full speed, and frozen at $-20^{\circ} \mathrm{C}$. In total, $60 \mathrm{OD}$ of cells were lysed in $500 \mu \mathrm{L}$ lysis buffer $(20 \mathrm{mM}$ Tris/ $\mathrm{HCl} \mathrm{pH} \mathrm{7.5,150} \mathrm{mM} \mathrm{KCl,} 10 \mathrm{mM} \mathrm{MgCl} 2,1 \mathrm{mM} \mathrm{DTT}$, $2 \mathrm{mM}$ PMSF) by glass beads ( $0.1 \mathrm{~mm}$, BioSpec Products) in the Retsch MM200 at $30 \mathrm{~Hz}$ for $10 \mathrm{~min}$ at $4^{\circ} \mathrm{C}$. The cell lysate was cleared at full speed for $10 \mathrm{~min}$ and the supernatant was transferred. $20 \mu \mathrm{L}$ RNase A/T1 mix $\left(2 \mu \mathrm{g} \mathrm{L}^{-1} / 5 \mathrm{U} \mu \mathrm{L}^{-1}\right.$, Thermo Scientific) was added to $100 \mu \mathrm{L}$ lysate $\left(\mathrm{OD}_{260} \sim 150\right)$ for RNase digestion for $20 \mathrm{~min}$ at $20^{\circ} \mathrm{C}$. The reaction was stopped on ice, diluted with 1 volume lysis buffer, and loaded completely onto a $10 \%-40 \%$ glycerol $(\mathrm{w} / \mathrm{v})$ gradient in lysis buffer. The proteins were sedimented in the SW40Ti rotor (Beckman Coulter) at $100,000 \mathrm{~g}$ for $17 \mathrm{~h}$ at $4^{\circ} \mathrm{C}$. The gradient was fractionated in 20 equal samples $(\sim 600 \mu \mathrm{L})$ from the top and the pellet was resuspended in an additional fraction. RNA was extracted by PCI for RNA (X985.3, Carl Roth) for RNA integrity control gels. Protein samples were prepared for SDS-PAGE analysis and western blotting.

We analyzed gradients with and without $0.2 \%$ Triton X100 in the lysis and gradient buffers (Supplemental Fig. S2G-I). Detergents solubilize membrane-associated proteins and prevent unspecific interactions, but also interfere with peptide recovery and mass spectrometric analysis. Both GradR experimental condition replicates were well correlated (Supplemental Fig. S2G-I, for details see section about data analysis) and we present here data of the GradR experiment without Triton X100 and complete in-solution MS sample preparation.

\section{In-solution MS sample preparation}

An amount of $0.2 \mu \mathrm{g}$ proteomics dynamic range standard set (UPS2, Sigma-Aldrich) was added as spike-in to $50 \mu \mathrm{L}$ protein samples of each fraction. Samples were diluted with two volumes denaturation buffer (100 mM Tris/HCl pH 8.5, $12 \mathrm{M}$ urea). $5 \mathrm{mM}$ tris(2-carboxyethyl)phosphine (TCEP, Bond-Breaker, neutral $\mathrm{pH}$, Thermo Scientific) was added and samples were incubated at room temperature for $20 \mathrm{~min}$. An amount of $10 \mathrm{mM}$ iodoacetamide (IAA) was added and samples were incubated at room temperature for $15 \mathrm{~min}$ in the dark. An amount of $0.25 \mu \mathrm{g}$ Lys-C protease (Promega) was added and incubated for $4 \mathrm{~h}$ at $37^{\circ} \mathrm{C}$. Samples were diluted with three volumes digestion buffer (100 $\mathrm{mM}$ Tris $/ \mathrm{HCl} \mathrm{pH} \mathrm{8.5,1} \mathrm{mM} \mathrm{CaCl}_{2}$ ) and $0.25 \mu \mathrm{g}$ Trypsin (Sequencing Grade, Promega) were added and incubated o/n at $37^{\circ} \mathrm{C}$. Five percentage of formic acid (FA) was added for acidification and samples were cleared by centrifugation at full-speed for $10 \mathrm{~min}$. Acidified sample supernatant was loaded onto methanol activated stage-tips (C18) by centrifugation for 5-10 min at $2000 \mathrm{~g}$. Tips were washed three times with washing solution $(2 \%$ acetonitrile [ACN], $0.3 \%$ trifluoroacetic acid [TFA]) and eluted in $0.5 \mathrm{~mL}$ protein-low bind tubes with two times $20 \mu \mathrm{L}$ elution solution (60\% ACN, 0.3\% FA). Samples were snap-frozen in liquid nitrogen and lyophilized. For liquid chromatography analysis, samples were solubilized in application solution ( $2 \%$ ACN, $0.1 \%$ FA), sonicated, and $12 \mu \mathrm{L}$ transferred to HPLC tubes.

\section{NanoLC-MS/MS analysis and MS analysis}

Samples were MS analyzed in the laboratory of Andreas Schlosser by Stephanie Lamer. NanoLC-MS/MS analyses were performed by an Orbitrap Fusion (Thermo Scientific) equipped with a PicoView lon Source (New Objective) and coupled to an EASYnLC 1000 (Thermo Scientific). Peptides were loaded on capillary columns (PicoFrit, $30 \mathrm{~cm} \times 150 \mu \mathrm{m}$ ID, New Objective) selfpacked with ReproSil-Pur 120 C18-AQ, $1.9 \mu$ m (r119.aq., Dr. Maisch). Samples were analyzed by a 120 min linear gradient from $3 \%-40 \%$ acetonitrile and $0.1 \%$ formic acid at a flow rate of $500 \mathrm{~nL} / \mathrm{min}$. MS and MS/MS scans were acquired in the Orbitrap analyzer with a resolution of 60,000 and 15,000 , respectively. Higher-energy collisional dissociation (HCD) fragmentation was applied with $35 \%$ normalized collision energy. We used top speed data-dependent MS/MS method with a fixed cycle time of $3 \mathrm{sec}$. Dynamic exclusion was applied with a repeat count of 1 and an exclusion duration of $60 \mathrm{sec}$ (singly charged precursors were excluded from selection). Minimum signal threshold for precursor selection was set to 50,000 . Predictive AGC was used with AGC a target value of $2 \times 10^{05}$ for MS scans and $5 \times 10^{04}$ for MS/ MS scans. EASY-IC was used for internal calibration.

Raw MS data files were analyzed with MaxQuant version 1.6.2.2 (Cox and Mann 2008). Database search was performed with Andromeda, which is integrated in the utilized version of MaxQuant. The search was performed against the UniProt Salmonella Typhimurium UP000008962 (strain SL1344) and a database containing the proteins of the UPS2 proteomic standard. Additionally, a database containing common contaminants was used. The search was performed with tryptic cleavage specificity with three allowed missed cleavages. Protein identification was under control of the false-discovery rate (FDR, $1 \%$ on protein and peptide (evel). In addition to MaxQuant default settings, the search was additionally performed for the following variable modifications: Protein amino-terminal acetylation, glutamine to pyro-glutamic acid formation (N-term. glutamine) and oxidation (methionine). Carbamidomethyl (cysteine) was set as fixed modification. For protein quantitation, the $\mathrm{iBAQ}$ intensities were used (Schwanhäusser et al. 2011). Proteins that could not be distinguished by peptides were listed individually. 


\section{Data analysis}

Relative protein abundance in gradient fractions were calculated by iBAQ. Absolute abundances were estimated by correcting for differences in digestion and C18 purification efficiency in each gradient fraction, through normalization to human albumin (Supplemental Table S1, norm. to spike-in, P02768ups|ALBU_HUMAN_UPS Serum albumin, chain 26-609, Supplemental Fig. S2A) that was added in equal amounts to each fraction as part of the UPS2 standard (Sigma-Aldrich). We selected albumin for normalization as the highest number of peptides (74) were recovered for it of all spike-in proteins. The protein ratio between reference and +RNase gradients was determined by the normalized total absolute protein abundance per gradient. For bar-diagram representation, the abundances for each individual protein were transformed into distributions across the gradient by dividing the abundance in each gradient fraction by the total abundance across the gradient (Supplemental Table S1, norm. to grad.). For visualization purposes, the $y$-axis of individual protein gradient profile plots were scaled to the largest value in either the reference or RNase treated gradient.

Relative protein level changes (d) per fraction (Fig. 4A) were determined by subtraction of the reference protein abundances from the RNase treated normalized protein abundances in each gradient fraction. These relative protein level changes per fraction were used for hierarchical clustering. The fraction of shifted protein was the sum of all positive relative protein level changes.

The mean position of a protein in a gradient was calculated as the mean of proportions of protein times each fraction number (pellet equals 21). The shift in protein distribution was calculated to capture the difference in relative protein positions between the reference and the RNase treated gradients (Supplemental Fig. S2A). Protein proportions were converted to binary vectors at two thresholds: $0.5 \%$ (to capture low abundance presence), and $2.5 \%$ (to capture more robust presence in a fraction). The Hamming distance was calculated for each protein between the reference and RNase-treated gradient at each threshold, providing a measure of similarity in protein presence and distribution profiles. The change in presence and distribution was then calculated as the mean of the Hamming distance at these two thresholds (Supplemental Fig. S2A).

Calculations were conducted in Microsoft Excel (Supplemental Table S1). All normalization operations are implemented in the Excel spread sheet and can be used for analysis of new data sets. Single-linkage hierarchical clustering on Euclidean distances was performed in Orange (3.23, University of Ljubljana [Demsar et al. 2013]). Thresholds were applied as indicated in the panels through the select row widget. The distance widget calculated the distances between rows, and hence individual proteins, and the hierarchical clustering widget yielded clusters in continuous order that were visualized as a heat map in Orange or Excel with color-coding that represented the shifting protein fraction from -1 to +1 normalized relative protein levels per gradient.

Scatter plots were assembled in Origin (OriginLabs) as bubble charts. Classification of proteins was achieved through consecutively requesting terms from protein names and full GO term annotation (without case sensitivity, from UniProt, UP000008962, release 12/2019 [The UniProt Consortium 2018]) in Microsoft Excel ("RNA," "riboso," "transla," and "nuclease" for the class RNA-binding; "DNA," "transcript," and "plasmid" for the class
DNA-binding; "nucleo," "metal," "zinc," "magnesium," "iron," "ATP," and "GTP" for the class metal- and nucleotide-binding; metabolism class proteins were derived from the Kyoto Encyclopaedia of Genes and Genomes (KEGG) database (sey00001, A09100 Metabolism, and subgroups); proteins annotated as both metal- and nucleotide-binding and metabolic proteins were extracted and are indicated as an isolated shared class; "membrane" for the two times class; "uncharacterized" for the uncharacterized class; proteins that remained unclassified were classified as others, or if only RNA- and DNA-binding proteins were shown, all others were classified as others). All other classifications are listed in Supplemental Table S4.

All figures were assembled in Adobe Illustrator. Pearson correlation coefficients between individual gradients or sedimentation profiles of proteins were calculated in Excel with the function "CORREL" considering norm. to gradient protein abundance. We observed well correlated sedimentation profiles for the reference gradient with Grad-seq profiles (Supplemental Fig. S2F). In addition, the nonshifting proteins were highly correlated between reference and RNase treated gradients in experimental condition replicates with (0.0) and without (0.1) $0.2 \%$ Triton X100 (Supplemental Fig. S2G-I).

\section{Genomic 3×FLAG-tag labeling of fopA in Salmonella enterica Typhimurium SL1344}

Constructs for recombination were amplified by PCR from genomic DNA with 35-45 nt $5^{\prime}$ and $3^{\prime}$ overhangs that were homologous to the recombination sites of the gene of interest. Wildtype Salmonella strain (JVO-1574) was transformed with pKD46 (Datsenko and Wanner 2000), selected by ampicillin resistance on a plate at $28^{\circ} \mathrm{C}$, picked and grown o/n in LB at $28^{\circ} \mathrm{C}$. LB media was inoculated with 1:300 o/n Salmonella +pKD46 (JVO-3013) culture with $0.2 \% \mathrm{~L}$ arabinose for $\lambda$ Red gene induction and expression. At OD 0.3 cells were placed on ice for $30 \mathrm{~min}$ and the culture was pelleted at $4000 \mathrm{~g}$ for $20 \mathrm{~min}$ at $4{ }^{\circ} \mathrm{C}$ and washed with ice-chilled water. The cell pellet was dissolved in 1/100 volume of initial culture. $50 \mu \mathrm{L}$ of competent cells were mixed with $100-300 \mathrm{ng}$ of the PCR product in a chilled $0.2 \mathrm{~cm}$ electroporation cuvette and transformed ( $200 \Omega, 25 \mu \mathrm{F}$, and $2.5 \mathrm{kV})$. Transformed cells were recovered in $500 \mu \mathrm{L}$ prewarmed LB media at $37^{\circ} \mathrm{C}$ and incubated for $2 \mathrm{~h}$. Cells were pelleted at $6000 \mathrm{~g}$ for $3 \mathrm{~min}$ at $25^{\circ} \mathrm{C}$ and selected by kanamycin resistance on a plate at $37^{\circ} \mathrm{C}$.

Single colonies were verified by PCR amplification of the cassette and chromosomal elements aside by verification primers, and selective growth with kanamycin and not with ampicillin; hence, the pKD46 plasmid was lost. To ensure only single insertion in the chromosomal region, P22 phage lysis and chromosomal integration was performed. The recipient strain (JVS-1574) was P22 phage lysed and the phage lysate was used for lysis of the donor strain. The donor strain phage lysate was then again used for transduction in the recipient strain. In detail, a single colony of the recipient strain was inoculated in $5 \mathrm{~mL}$ LB media and grown to OD 1.0. An amount of $10 \mu \mathrm{L}$ of P22 lysate was added and the cells were grown $\mathrm{o} / \mathrm{n}$ at $37^{\circ} \mathrm{C}$. The suspension was pelleted at $14,000 \mathrm{~g}$ for $10 \mathrm{~min}$ at $4^{\circ} \mathrm{C}$. The supernatant was transferred to glass tubes and extracted with $200 \mu \mathrm{L}$ chloroform to kill all remaining bacteria. The recipient $\mathrm{P} 22$ lysate was stored at $4^{\circ} \mathrm{C}$ and used for lysis of the donor strain. 
For integration of the fragment from the P22 lysate into the recipient strain, $100 \mu \mathrm{L}$ of OD1 recipient strain were infected with 10-30 $\mu \mathrm{L}$ phage lysate for $20 \mathrm{~min}$ at room temperature. The infection was quenched with $20 \mathrm{mM}$ EGTA to allow only one round of infection. The cells were recovered in $1 \mathrm{~mL} L B$ media for $2 \mathrm{~h}$ and plated on plates with kanamycin. The kanamycin cassette was removed by FRT recombination and transformation of $\mathrm{pCP} 20$ at $28^{\circ} \mathrm{C}$. pKD46 and pCP20 were removed by o/n incubation at $42^{\circ} \mathrm{C}$ and selection of single colonies on plates with corresponding antibiotics. Strains that were only growing on LB plates were considered as cured and used for studies.

\section{Western blotting}

Protein samples were diluted in reducing $1 \times$ protein-sample loading buffer $(60 \mathrm{mM}$ Tris-HCl pH 6.8, $0.2 \mathrm{~g} / \mathrm{mL}$ SDS, $0.1 \mathrm{mg} / \mathrm{mL}$ bromphenol blue, $77 \mathrm{mg} / \mathrm{mL}$ DTT, $10 \%$ glycerol) and boiled at $100^{\circ} \mathrm{C}$ for $5 \mathrm{~min}$ and loaded on SDS-PAGE. In the case of Hfq-FLAG, samples were heated to $90^{\circ} \mathrm{C}$. The gel was blotted by semi-dry transfer on polyvinylidene fluoride (PVDF) membranes and probed with tagspecific antibodies. For FLAG-tag detection, a monoclonal antibody was used (\#F1804, 1:2000 dilution, Sigma-Aldrich). GroEL was detected after stripping with anti-GroEL rabbit anti-body (\#G6532, 1:10,000 dilution, Sigma-Aldrich).

\section{Coimmunoprecipitation (Co-IP)}

Sixty OD of cells at OD 2 were resuspended in $800 \mu \mathrm{L}$ lysis buffer (20 mM Tris/HCl pH 8.0, $150 \mathrm{mM} \mathrm{KCl}, 1 \mathrm{mM} \mathrm{MgCl} 2,1 \mathrm{mM} \mathrm{DTT}$ ), and $800 \mu \mathrm{L} 0.1 \mathrm{~mm}$ glass beads (BioSpecs). Cells were lysed at $30 \mathrm{~Hz}$ for $10 \mathrm{~min}$ in the Retsch MM200 at $4^{\circ} \mathrm{C}$. The lysate was cleared twice for $10 \mathrm{~min}$ at full-speed at $4^{\circ} \mathrm{C}$. An amount of $35 \mu \mathrm{L}$ monoclonal anti-FLAG M2 antibody produced in mouse (Sigma-Aldrich) was added to the supernatant and incubated for $30 \mathrm{~min}$ at $4^{\circ} \mathrm{C}$. An amount of $75 \mu \mathrm{L}$ prewashed protein A sepharose (Sigma-Aldrich) was added for recovery of FLAG-antibody and incubated for $30 \mathrm{~min}$. Beads were pelleted at $300 \mathrm{~g}$ and washed five times with lysis buffer, resuspended in $500 \mu \mathrm{L}$ lysis buffer and extracted with $\mathrm{PCl}$. The aqueous layer was precipitated with ethanol and 1:30 $3 \mathrm{M}$ sodium acetate at $\mathrm{pH} 5.2$ at $-20^{\circ} \mathrm{C}$ overnight. The precipitated RNA was pelleted and washed with $500 \mu \mathrm{L} 75 \%$ ethanol. The pellet was dried and solubilized in $15.5 \mu \mathrm{L}$ water. DNA was degraded by DNase I (Thermo Scientific) as described in the manual in the presence of RNase inhibitor for $30 \mathrm{~min}$ at $37^{\circ} \mathrm{C}$. The sample was diluted with $100 \mu \mathrm{L}$ water and the RNA was extracted by $\mathrm{PCl}$. The RNA was solubilized to an $\mathrm{OD}_{260}$ of 1 and analyzed in the Bioanalyzer (Agilent) for quality and quantity estimation for RNA-seq. Protein samples were recovered from the organic layer by $10 \mathrm{vol}$ methanol precipitation.

\section{RNA-seq}

RNA library preparation was conducted by the Core Unit SysMed (Kristina Döring, Würzburg). An amount of 200 ng eluted RNA from the colP was denatured at $70^{\circ} \mathrm{C}$ for $2 \mathrm{~min}$, cooled down on ice, and $3^{\prime}$-end dephosphorylated by 10 U T4-PNK (M0201S, $\mathrm{NEB}$ ) in the presence of $20 \mathrm{U}$ RNase inhibitor (M0314L, NEB) for $60 \mathrm{~min}$ at $37^{\circ} \mathrm{C}$. An amount of $1.6 \mathrm{mM}$ ATP and $10 \mathrm{U}$ PNK was added for $5^{\prime}$-end phosphorylation for $60 \mathrm{~min}$ at $37^{\circ} \mathrm{C}$. RNA was purified by silica-based columns (Zymo RNA Clean \& Concentrator kit, R1013, Zymo Research) and eluted in $15 \mu \mathrm{L}$ nuclease-free water (436912C, VWR). RNA was denatured again and pyrophosphates were removed from the 5'-end by $10 \mathrm{U} \mathrm{RppH}$ (M0356S, NEB) in 1× NEB buffer $2(10 \mathrm{mM}$ Tris- $\mathrm{HCl} \mathrm{pH} 7.9$, $50 \mathrm{mM} \mathrm{NaCl}, 10 \mathrm{mM} \mathrm{MgCl}, 1 \mathrm{mM}$ DTT) in the presence of $20 \mathrm{U}$ RNase inhibitor for $60 \mathrm{~min}$ at $37^{\circ} \mathrm{C}$, and again column purified and eluted in $6 \mu \mathrm{L}$. For $3^{\prime}$ adaptor ligation the NEBNext Small RNA Kit (E7560S, NEB) was used: 200 ng RNA were mixed with $1 \mu \mathrm{L}$ 1:3 diluted 3' SR adaptors for Illumina, and denatured, $1 \times$ $3^{\prime}$ ligation reaction buffer was added and $3 \mu \mathrm{L}$ ligation enzyme mix in a total volume of $20 \mu \mathrm{L}$ for $60 \mathrm{~min}$ at $25^{\circ} \mathrm{C}$. An amount of $1 \mu \mathrm{L} 1: 3$ diluted SR RT-primer for Illumina was added in a total volume of $25 \mu \mathrm{L}$. The annealing was conducted at $75^{\circ} \mathrm{C}$ for $5 \mathrm{~min}, 37^{\circ} \mathrm{C}$ at $15 \mathrm{~min}, 25^{\circ} \mathrm{C}$ at $15 \mathrm{~min}$, cooling at $4^{\circ} \mathrm{C}$. An amount of $1 \mu \mathrm{l} 5^{\prime}$ SR adaptor for Illumina (freshly solubilized, denatured, and cooled on ice), $1 \mu \mathrm{L} 10 \times 5^{\prime}$ ligation reaction buffer, and $2.5 \mu \mathrm{L} 5^{\prime}$ ligation enzyme mix were added to the reaction and incubated for $60 \mathrm{~min}$ at $25^{\circ} \mathrm{C}$. For reverse transcription, $8 \mu \mathrm{L}$ first strand synthesis reaction buffer, $1 \mu \mathrm{L}$ murine RNase inhibitor, and $1 \mu \mathrm{L}$ ProtoScript II reverse transcriptase were added and incubated for $60 \mathrm{~min}$ at $50^{\circ} \mathrm{C}$. PCR amplification of reverse transcripts was conducted by addition of $50 \mu \mathrm{L}$ LongAmp Taq $2 \times$ master mix, $5 \mu \mathrm{L}$ nuclease free water, $2.5 \mu \mathrm{L}$ 1:3 diluted SR primer for Illumina, and $2.5 \mu \mathrm{L} 1: 3$ diluted index primers. The reaction was cycled at $94^{\circ} \mathrm{C}$ for $30 \mathrm{sec}, 14 \times 94^{\circ} \mathrm{C}$ for $15 \mathrm{sec}-62^{\circ} \mathrm{C}$ for $30 \mathrm{~s}-70^{\circ} \mathrm{C}$ for $90 \mathrm{sec}, 70^{\circ} \mathrm{C}$ for $5 \mathrm{~min}$, and cooled at $4^{\circ} \mathrm{C}$.

DNA was purified by MagSi-NGSPREP Plus (MDKT00010005, Steinbrenner Laborsysteme $\mathrm{GmbH}$ ) beads with a ratio of $1.8 \times$ to reaction volume. All steps were executed in DNA-LoBind tubes (\#0030108051, Eppendorf). The final supernatant was analyzed by Qubit 2.0 (Thermo Scientific) with the dsDNA HS Assay Kit (Q32854, Thermo Scientific) and the Bioanalyzer 2100 (G2939BA, Agilent) with the DNA 1000 kit (5067-1504) or HS DNA 7500 kit (5067-1506). The sample was sequenced on the NextSeq-500 system (Illumina) with a read depth of 5 mio. reads per sample and a read length of 75 nt single end.

\section{RNA-seq analysis}

Reads were mapped to the Salmonella reference sequences (NC_016810.1, NC_017718.1, NC_017719.1, and NC_0177 20.1) by the READemption align function (READemption version 0.4.3 [Förstner et al. 2014]). Coverage wig-files were generated with the coverage function and read allocation to genomic features was quantified by the gene_quanti function. Annotation of $3^{\prime} / 5^{\prime}$ UTRs was used from the Hinton laboratory and sRNAs from the Vogel laboratory. Overlaid annotations that caused multiple entries were manually corrected. Sequencing coverages were visualized in the Integrative Genomics Viewer (IGV, Broad Institute [Robinson et al. 2011]) based on uniquely mapped reads and normalized to the total number of aligned reads.

\section{RNA production}

Template DNA for transcription from a T7 promoter was produced by PCR and extracted from agarose gel or purified by anion-exchange columns, or reverse-complementary primers were 
annealed as DNA template. RNA was produced with the T7 MEGAscript kit (Thermo Scientific), 200 ng DNA template was mixed in a $20 \mu \mathrm{L}$ transcription reaction, with $2 \mu \mathrm{L}$ of each nucleotide, $2 \mu \mathrm{L}$ enzyme mix, and $2 \mu \mathrm{L} 10 \times$ reaction buffer, and incubated for $6 \mathrm{~h}$ to overnight at $37^{\circ} \mathrm{C}$. An amount of $1 \mu \mathrm{L}$. Turbo DNase I $(1 \mathrm{U} / \mu \mathrm{L})$ was added and incubated for $15 \mathrm{~min}$. An amount of $15 \mu \mathrm{L} 5 \mathrm{M}$ ammonium acetate, 100 mM EDTA ( $\mathrm{pH}$ 8.0) were added and the sample was filled up to $100 \mu \mathrm{L}$ with water and extracted with $\mathrm{PCl}$. The aqueous phase was rebuffered through a G25 spin-column and sample was eluted in water, and precipitated with $7.5 \mathrm{mM} \mathrm{NaOAc} \mathrm{pH} 5.2$ and 75\% ethanol. The pellet was washed with $75 \%$ ethanol, air-dried, and solubilized in nucleasefree water. RNA quantity and quality was assayed by Urea-PAGE and Stain-All $(0.075 \mathrm{mg} / \mathrm{mL}$ in $60 \%$ formamide, autoclaved, E9379, Sigma-Aldrich) staining.

\section{$5^{\prime}{ }^{32}$ P-labeling of RNA}

RNA for EMSA, structure probing, or kinetic studies, or DNA oligo for northern probing were radioactively labeled by polynucleotide kinase. In a total reaction of $10 \mu \mathrm{L}$, up to 100 pmol RNA or DNA were mixed with $2.5 \mathrm{pmol} \gamma-{ }^{32} \mathrm{P}-\mathrm{ATP}(1 \mu \mathrm{L}, 400 \mathrm{mCi} / \mu \mathrm{mol}$, $10 \mu \mathrm{Ci} / \mu \mathrm{L}$, Hartmann Analytic) in $1 \times$ kinase buffer (80 mM Tris$\mathrm{HCl} \mathrm{pH} \mathrm{7.5,} 10 \mathrm{mM} \mathrm{MgCl} 2,5 \mathrm{mM}$ DTT), and $1 \mu \mathrm{L} \mathrm{T4-PNK} \mathrm{(10} \mathrm{U/}$ $\mu \mathrm{L}, \mathrm{EK} 0031$, Thermo Scientific). The reaction was incubated at $37^{\circ} \mathrm{C}$ for $40 \mathrm{~min}$. Free nucleotides were removed with a spin column (Illustra MicroSpin G-25 Columns, GE Healthcare) at $750 \mathrm{~g}$ for 2 min. The labeled RNA/DNA was eluted in $20 \mu \mathrm{L}$ water. Alternatively, the reaction was extracted by $\mathrm{PCl}$ for nucleotides (A156.3, Carl Roth), and precipitated by ethanol.

\section{FopA protein expression and purification}

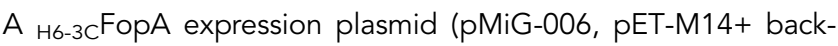
bone, kanamycin resistance, cloned by "Recombinant Protein Expression Facility," Rudolf-Virchow-Center) was transformed into E. coli BL21-CodonPlus (DE3)-RIL cells (Agilent Technologies, JVS-12280, chloramphenicol resistance). Cells were grown in $L B$ to $\mathrm{OD}_{600} 0.6$ at $37^{\circ} \mathrm{C}$, cooled to $18^{\circ} \mathrm{C}$ and induced with $0.5 \mathrm{mM}$ IPTG overnight. Cells were resuspended in lysis buffer (50 mM sodium phosphate $\mathrm{pH} 8.0,1 \mathrm{M} \mathrm{NaCl}, 1 \mathrm{mM}$ TCEP, 1 mM PMSF) and disrupted by sonication (50\% amplitude, $30 \mathrm{sec}$ pulsation-30 sec break for $5 \mathrm{~min}$, on ice, Sonopuls HD 3200, TT13 tip, Bandelin). The lysate was cleared at 15,000 g for 15 min at $4^{\circ} \mathrm{C}$. Equilibrated Protino Ni-IDA beads (Macherey-Nagel) were added to the supernatant and incubated for $1 \mathrm{~h}$ at $4^{\circ} \mathrm{C}$ in an overhead rotor. Beads were recovered and washed with lysis buffer.

Protein was recovered in elution buffer $(50 \mathrm{mM}$ sodium phosphate $\mathrm{pH}$ 8.0, $200 \mathrm{mM}$ imidazole, $1 \mathrm{mM}$ TCEP), rebuffered by centrifugal filtration (Amicon Ultra, Merck Millipore, cut-off $10 \mathrm{kDa}$ ) in 3C-cleavage buffer $(50 \mathrm{mM}$ Tris/ $\mathrm{HCl} \mathrm{pH} \mathrm{7.5,150} \mathrm{mM} \mathrm{NaCl}, 0.1$ $\mathrm{mM}$ EDTA, $1 \mathrm{mM}$ TCEP) and incubated overnight with $3 \mathrm{C}$ protease at $4^{\circ} \mathrm{C}$. Ni-IDA beads were added to the sample for removal of the cleaved tag and the protease. The supernatant was diluted $1: 50$ in cation exchange buffer $\mathrm{A}(50 \mathrm{mM}$ sodium phosphate $\mathrm{pH}$ 6.0, $20 \mathrm{mM} \mathrm{NaCl}, 0.1 \mathrm{mM}$ EDTA, $1 \mathrm{mM}$ TCEP). The sample was applied to a mono S 5/50 GL (GE) column and eluted in a salt gradient to $1 \mathrm{M} \mathrm{NaCl}$. FopA eluted at about $0.7 \mathrm{M} \mathrm{NaCl}$. The protein was concentrated and rebuffered in storage buffer $(20 \mathrm{mM}$ sodium phosphate $\mathrm{pH} 7.0,100 \mathrm{mM} \mathrm{NaCl}$ ) through centrifugal filtration and flash frozen in liquid nitrogen. The concentration of FopA was determined spectrophotometrically utilizing the extinction coefficient of $21,000 \mathrm{mM}^{-1} \mathrm{~cm}^{-1}$.

\section{Electrophoretic mobility shift assay}

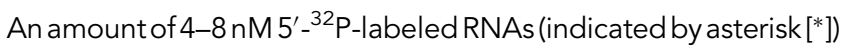
were mixed optionally with an equal amount of repZand incubated for $5 \mathrm{~min}$ at $37^{\circ} \mathrm{C}$ in reaction buffer $(25 \mathrm{mM}$ Tris/ $\mathrm{HCl} \mathrm{pH} \mathrm{7.4,} 150 \mathrm{mM}$ $\mathrm{NaCl}, 1 \mathrm{mM} \mathrm{MgCl}$ ). An amount of $0.1 \mathrm{mg} / \mathrm{mL}$ yeast RNA (10 mg/ $\mathrm{mL}$, Merck) was added. Final concentration of 0-5 $\mu \mathrm{M}$ FopA was added and incubated for $15 \mathrm{~min}$ at $37^{\circ} \mathrm{C}$. Subsequently, $3 \mu \mathrm{L} 5 \times$ native loading dye $(0.5 \times \mathrm{TBE}, 50 \%[\mathrm{v} / \mathrm{v}]$ glycerol, $0.2 \%[\mathrm{w} / \mathrm{v}]$ xylene cyanol, $0.2 \%[\mathrm{w} / \mathrm{v}]$ bromphenol blue) was added and loaded immediately on a running native $6 \%$ polyacrylamide/0.5 $\times$ TBE gel and run for $2-3 \mathrm{~h}$ at $40 \mathrm{~mA}$ at $4{ }^{\circ} \mathrm{C}$. The gel was dried on filterpaper. The membrane was wrapped in foil and exposed to a photostimulatable phosphor plate and the signal was detected by the Typhoon 7000 phosphoimager (GE Healthcare).

\section{RNA-RNA complex formation kinetics}

Kinetics of complex formation between Inc and repZ were determined as described previously (Persson et al. 1988; Asano et al. 1998). An amount of $1 \mathrm{nM}{ }^{32} \mathrm{P}$-labeled Inc RNA (denatured by boiling and cooled to $37^{\circ} \mathrm{C}$ ) was mixed optionally with $200 \mathrm{nM}$ FopA and incubated for $10 \mathrm{~min}$ at $37^{\circ} \mathrm{C}$ in reaction buffer (20 mM Tris/ $\mathrm{HCl} \mathrm{pH} \mathrm{7.5,} 1 \mathrm{mM} \mathrm{MgCl} 2,150 \mathrm{mM} \mathrm{NaCl}$ ). An amount of $25 \mathrm{nM}$ repZ was added and immediately time points were taken by dilution with 2 volumes in application buffer (92\% deionized formamide, 17 mM EDTA, 0.025\% xylene cyanol, 0.025\% bromphenol blue) and loaded onto a running and cooled $8.3 \mathrm{M}$ Urea-PAGE gel at $40 \mathrm{~W}$ for $2 \mathrm{~h}$. For the $0 \mathrm{sec}$ time point, Inc ( \pm FopA) was quenched with two volumes application buffer and then repZ was added and loaded immediately onto the running gel. The kinetics of the complex formation were calculated by the pseudo-first-order rate constant $k_{1}{ }^{\prime}=\ln (2) / t_{1 / 2}\left(t_{1 / 2}\right.$ was determined from the plot) that is related to the second-order rate constant $k_{2}=k_{1}{ }^{\prime} /[$ repZ], as described previously (Persson et al. 1988).

\section{Structure probing}

$5^{\prime}-{ }^{32} \mathrm{P}$-labeled Inc (Inc ${ }^{*}$ ) and repZ RNA were denatured at $95^{\circ} \mathrm{C}$ for $3 \mathrm{~min}$ and cooled slowly down to $37^{\circ} \mathrm{C}$ in reaction buffer $(25 \mathrm{mM}$ Tris- $\mathrm{HCl} \mathrm{pH} \mathrm{7.4,} 150 \mathrm{mM} \mathrm{NaCl}, 1 \mathrm{mM} \mathrm{MgCl} 2$ ). An amount of $15 \mathrm{nM}$ Inc* was incubated optionally with $15 \mathrm{nM}$ repZ at $37^{\circ} \mathrm{C}$ for $5 \mathrm{~min}$ in reaction buffer. A final concentration of $0.1 \mathrm{mg} / \mathrm{mL}$ yeast RNA (AM7118, Thermo Scientific) was added, incubated for $1 \mathrm{~min}$, and optionally $5 \mu \mathrm{M}$ of FopA (His-tag cleaved off by $3 \mathrm{C}$ protease) were added to a final volume of $10 \mu \mathrm{L}$ and incubated for $15 \mathrm{~min}$ at $37^{\circ} \mathrm{C}$ to allow binding. In a total reaction of $12 \mu \mathrm{L}$, $0.002 \mathrm{U} / \mu \mathrm{L}$ RNase T1 (1 U/ $\mu \mathrm{L}, \mathrm{AM} 2283$, Thermo Scientific) was added and incubated for $3 \mathrm{~min}$, or $0.001 \mathrm{ng} / \mu \mathrm{L}$ RNase $A$ (10 mg/mL, EN0531, Thermo Scientific) for $3 \mathrm{~min}$. For the ladder, $30 \mathrm{nM}$ Inc* RNA was incubated for $5 \mathrm{~min}$ at $95^{\circ} \mathrm{C}$ in $10 \mu \mathrm{L}$ alkaline hydrolysis buffer (50 mM sodium carbonate $\mathrm{pH}$ 9.2, $1 \mathrm{mM}$ EDTA), or for $3 \mathrm{~min}$ at $37^{\circ} \mathrm{C}$ with $0.01 \mathrm{U} / \mu \mathrm{L}$ RNase T1. The reactions were 
quenched with $50 \mathrm{mM}$ EDTA, 0.3 M NaOAc pH 5.2, 50\% formamide (deionized, P040.1, Carl Roth), and 2\% SDS. The samples were boiled for $5 \mathrm{~min}$ at $95^{\circ} \mathrm{C}$, cooled down on ice. Samples were diluted with water and extracted with an equal volume of PCl for RNA (X985.3, Carl Roth). RNA in the aqueous phase was precipitated overnight at $-20^{\circ} \mathrm{C}$ with $80 \%$ ice-cold ethanol, $0.06 \mathrm{M} \mathrm{NaOAc} \mathrm{pH} 5.2,0.2 \mathrm{mM} \mathrm{MgCl}$, and $1 \mu \mathrm{L}$ GlycoBlue (15 mg/ml, AM9515, Thermo Scientific) was added as tracer. After pelleting at full-speed and $4^{\circ} \mathrm{C}$, the pellet was washed with ice-cold $75 \%$ ethanol, and the supernatant removed, and evaporated. The RNA was solubilized in GLII buffer (95\% deionized formamide, $0.02 \%$ SDS, $0.02 \%$ bromphenol blue, $0.01 \%$ xylene cyanol, and $1 \mathrm{mM}$ EDTA) for $5 \mathrm{~min}$ at $60^{\circ} \mathrm{C}$, boiled at $95^{\circ} \mathrm{C}$ for $5 \mathrm{~min}$. The hot sample was loaded onto a prerun ( $45 \mathrm{~W}$ for $1 \mathrm{~h})$ and hot 10\% 7 M Urea-PAGE gel in 1× TBE buffer ( 89 mM Tris, 89 boric acid, $2 \mathrm{mM}$ EDTA, $\mathrm{pH} \sim 8.3$ ). When the running front reached nearly the end. The gel was transferred onto filter-paper, sealed from the top with foil, and dried in the Gel Dryer Model 543 (Bio-Rad) for $1 \mathrm{~h}$ with heating. The gel was set onto a photostimulatable storage phosphor screen and the signal was detected by the Typhoon 7000 phosphorimager (GE Healthcare).

\section{DATA DEPOSITION}

MS data are accessible at the ProteomeXchange consortium (Deutsch et al. 2016) via the PRIDE partner repository (PerezRiverol et al. 2018) with the data set identifier PXD018422. Raw data after MaxQuant analysis are listed in Supplemental Table 1 in the tab "RAW."

The python code for the GradR browser is deposited at Zenodo 3742229 (DOI:10.5281/zenodo.3742229).

The GradR browser is accessible online at www.helmholtz-hiri .de/en/datasets/GradRSeT. FopA colP-seq raw FASTQ and analyzed WIG coverage files are accessible at Gene Expression Omnibus (GEO [Edgar et al. 2002]) with accession no. GSE148184.

READemption 0.4.5 is deposited at Zenodo 1134354 (DOI: 10.5281/zenodo.1134354). The READemption analysis folder is deposited at Zenodo 3742725 (DOI:10.5281/zenodo.3742 725).

\section{SUPPLEMENTAL MATERIAL}

Supplemental material is available for this article.

\section{ACKNOWLEDGMENTS}

We are grateful to Barbara Plaschke for technical assistance; Alexander Westermann, Jens Hör, Andreas Schlosser, Stephanie Lamer, and all laboratory members for helpful discussions; Benedikt Beckmann, Cynthia Sharma, and Gisela Storz for providing comments on the manuscript.

Author contributions: M.G. and J.V. designed experiments. M. G. performed all experiments unless stated otherwise. M.G. and J.K. purified protein, C.K. provided resources. M.G. performed and L.B. validated data analysis. M.G. programmed the GradR browser. M.G. and J.V. wrote the paper with input from Y.E.M. All authors approved the final version.

Received June 22, 2020; accepted June 29, 2020.

\section{REFERENCES}

Argaman L, Elgrably-Weiss M, Hershko T, Vogel J, Altuvia S. 2012. RelA protein stimulates the activity of RyhB small RNA by acting on RNA-binding protein Hfq. Proc Natl Acad Sci 109: 46214626. doi:10.1073/pnas.1113113109

Arthur DC, Ghetu AF, Gubbins MJ, Edwards RA, Frost LS, Glover JNM. 2003. FinO is an RNA chaperone that facilitates sense-antisense RNA interactions. EMBO J 22: 6346-6355. doi:10.1093/emboj/cdg607

Arthur DC, Edwards RA, Tsutakawa S, Tainer JA, Frost LS, Glover JNM. 2011. Mapping interactions between the RNA chaperone FinO and its RNA targets. Nucleic Acids Res 39: 4450-4463. doi:10.1093/nar/gkr025

Asano K, Niimi T, Yokoyama S, Mizobuchi K. 1998. Structural basis for binding of the plasmid Collb-P9 antisense Inc RNA to its target RNA with the $5^{\prime}$-rUUGGCG-3' motif in the loop sequence. J Biol Chem 273: 11826-11838. doi:10.1074/jbc.273.19.11826

Asano K, Hama C, Inoue S, Moriwaki H, Mizobuchi K. 1999. The plasmid Collb-P9 antisense Inc RNA controls expression of the RepZ replication protein and its positive regulator repY with different mechanisms. J Biol Chem 274: 17924-17933. doi:10.1074/jbc .274.25.17924

Asencio C, Chatterjee A, Hentze MW. 2018. Silica-based solid-phase extraction of cross-linked nucleic acid-bound proteins. Life Sci Alliance 1: e201800088. doi:10.26508/lsa.201800088

Attaiech L, Boughammoura A, Brochier-Armanet C, Allatif O, PeillardFiorente F, Edwards RA, Omar AR, MacMillan AM, Glover M, Charpentier $X$. 2016. Silencing of natural transformation by an RNA chaperone and a multitarget small RNA. Proc Natl Acad Sci 113: 8813-8818. doi:10.1073/pnas. 1601626113

Attaiech L, Glover JNM, Charpentier X. 2017. RNA chaperones step out of Hfq's shadow. Trend Microbiol 25: 247-249. doi:10.1016/ j.tim.2017.01.006

Babitzke P, Lai Y-J, Renda A, Romeo T. 2019. Posttranscription initiation control of gene expression mediated by bacterial RNA-binding proteins. Annu Rev Microbiol 73: 43-67. doi:10.1146/annurevmicro-020518-115907

Bao X, Guo X, Yin M, Tariq M, Lai Y, Kanwal S, Zhou J, Li N, Lv Y, Pulido-Quetglas $C$, et al. 2018. Capturing the interactome of newly transcribed RNA. Nat Methods 15: 213-220. doi:10.1038/ nmeth.4595

Bauriedl S, Gerovac M, Heidrich N, Bischler T, Barquist L, Vogel J, Schoen C. 2020. The minimal meningococcal ProO protein has an intrinsic capacity for structure-based global RNA recognition. Nat Commun 11: 2823. doi:10.1038/s41467-020-16650-6

Benjamin J-AM, Massé E. 2014. The iron-sensing aconitase B binds its own mRNA to prevent sRNA-induced mRNA cleavage. Nucleic Acids Res 42: 10023-10036. doi:10.1093/nar/gku649

Biesen T, Frost LS. 1994. The FinO protein of IncF plasmids binds FinP antisense RNA and its target, traJ mRNA, and promotes duplex formation. Mol Microbiol 14: 427-436. doi:10.1111/j.1365-2958 .1994.tb02177.x

Boehringer D, O'Farrell HC, Rife JP, Ban N. 2012. Structural insights into methyltransferase KsgA function in 30 S ribosomal subunit biogenesis. J Biol Chem 287: 10453-10459. doi:10.1074/jbc.M111 .318121

Browne HP, Forster SC, Anonye BO, Kumar N, Neville BA, Stares MD, Goulding D, Lawley TD. 2016. Culturing of 'unculturable' human microbiota reveals novel taxa and extensive sporulation. Nature 533: 543-547. doi:10.1038/nature17645

Burley SK, Berman HM, Bhikadiya C, Bi C, Chen L, Di Costanzo L, Christie C, Dalenberg K, Duarte JM, Dutta S, et al. 2018. RCSB Protein Data Bank: biological macromolecular structures enabling research and education in fundamental biology, biomedicine, 
biotechnology and energy. Nucleic Acids Res 47: D464-D474. doi:10.1093/nar/gky1004

Canals R, Hammarlof DL, Kroger C, Owen SV, Fong WY, LacharmeLora L, Zhu X, Wenner N, Carden SE, Honeycutt J, et al. 2019. Adding function to the genome of African Salmonella Typhimurium ST313 strain D23580. PLoS Biol 17: e3000059. doi:10.1371/journal.pbio.3000059

Caudron-Herger M, Rusin SF, Adamo ME, Seiler J, Schmid VK, Barreau E, Kettenbach AN, Diederichs S. 2019. R-DeeP: proteome-wide and quantitative identification of RNA-dependent proteins by density gradient ultracentrifugation. Mol Cell 75: 184 199. doi:10.1016/j.molcel.2019.04.018

Chao Y, Papenfort K, Reinhardt R, Sharma CM, Vogel J. 2012. An atlas of Hfq-bound transcripts reveals 3' UTRs as a genomic reservoir of regulatory small RNAs. EMBO J 31: 4005-4019. doi:10.1038/ emboj.2012.229

Chaulk SG, Smith-Frieday MN, Arthur DC, Culham DE, Edwards RA, Soo P, Frost LS, Keates RAB, Glover JNM, Wood JM. 2011. ProO is an RNA chaperone that controls ProP levels in Escherichia coli. Biochemistry 50: 3095-3106. doi:10.1021/bi101683a

Chen Y, Anderson DM. 2011. Expression hierarchy in the Yersinia type III secretion system established through YopD recognition of RNA. Mol Microbiol 80: 966-980. doi:10.1111/j.1365-2958 .2011.07623.x

Cox J, Mann M. 2008. MaxQuant enables high peptide identification rates, individualized p.p.b.-range mass accuracies and proteomewide protein quantification. Nat Biotechnol 26: 1367-1372. doi:10 $.1038 / n b t .1511$

Datsenko KA, Wanner BL. 2000. One-step inactivation of chromosomal genes in Escherichia coli K-12 using PCR products. Proc Natl Acad Sci 97: 6640-6645. doi:10.1073/pnas.120163297

Demsar J, Curk T, Erjavec A, Gorup C, Hocevar T, Milutinovic M, Mozina M, Polajnar M, Toplak M, Staric A, et al. 2013. Orange: data mining toolbox in Python. J Mach Learn Res 14: 2349-2353.

Deutsch EW, Csordas A, Sun Z, Jarnuczak A, Perez-Riverol Y, Ternent T, Campbell DS, Bernal-Llinares M, Okuda S, Kawano S, et al. 2016. The ProteomeXchange consortium in 2017: supporting the cultural change in proteomics public data deposition. Nucleic Acids Res 45: D1100-D1106. doi:10.1093/nar/gkw936

Edgar R, Domrachev M, Lash AE. 2002. Gene Expression Omnibus: NCBI gene expression and hybridization array data repository. Nucleic Acids Res 30: 207-210. doi:10.1093/nar/30.1.207

El-Gebali S, Mistry J, Bateman A, Eddy SR, Luciani A, Potter SC, Qureshi M, Richardson LJ, Salazar GA, Smart A, et al. 2018. The Pfam protein families database in 2019. Nucleic Acids Res 47: D427-D432. doi:10.1093/nar/gky995

Feng B, Mandava CS, Guo Q, Wang J, Cao W, Li N, Zhang Y, Zhang Y, Wang Z, Wu J, et al. 2014. Structural and functional insights into the mode of action of a universally conserved Obg GTPase. PLoS Biol 12: e1001866. doi:10.1371/journal.pbio.1001866

Förstner KU, Vogel J, Sharma CM. 2014. READemption-a tool for the computational analysis of deep-sequencing-based transcriptome data. Bioinformatics 30: 3421-3423. doi:10.1093/bioinformatics/ btu533

Genschik P, Drabikowski K, Filipowicz W. 1998. Characterization of the Escherichia coli RNA 3'-terminal phosphate cyclase and its 554 regulated operon. J Biol Chem 273: 25516-25526. doi:10.1074/ jbc.273.39.25516

Gerovac M, Vogel J. 2019. An RNA surprise in bacterial effector mechanisms. Cell Host Microbe 26: 709-711. doi:10.1016/j.chom.2019 11.005

Ghetu AF, Gubbins MJ, Frost LS, Glover JNM. 2000. Crystal structure of the bacterial conjugation repressor FinO. Nat Struct Biol 7: 565569. doi: $10.1038 / 76790$
Ghetu AF, Arthur DC, Kerppola TK, Glover JNM. 2002. Probing FinOFinP RNA interactions by site-directed protein-RNA crosslinking and gelFRET. RNA (New York, NY) 8: 816-823. doi:10.1017/ S1355838202026730

Gonzalez GM, Hardwick SW, Maslen SL, Skehel JM, Holmqvist E, Vogel J, Bateman A, Luisi BF, Broadhurst RW. 2017. Structure of the Escherichia coli ProQ RNA-binding protein. RNA (New York, NY) 23: 696-711. doi:10.1261/rna.060343.116

Gros F, Hiatt H, Gilbert W, Kurland CG, Risebrough RW, Watson JD. 1961. Unstable ribonucleic acid revealed by pulse labelling of Escherichia coli. Nature 190: 581-585. doi:10.1038/190581a0

Halic M, Becker T, Pool MR, Spahn CMT, Grassucci RA, Frank J, Beckmann R. 2004. Structure of the signal recognition particle interacting with the elongation-arrested ribosome. Nature 427: 808-814. doi:10.1038/nature02342

Hentze MW, Castello A, Schwarzl T, Preiss T. 2018. A brave new world of RNA-binding proteins. Nat Rev Mol Cell Biol 19: 327-341. doi:10.1038/nrm.2017.130

Holmqvist E, Vogel J. 2018. RNA-binding proteins in bacteria. Nat Rev Microbiol 16: 601-615. doi:10.1038/s41579-018-0049-5

Holmqvist E, Wright PR, Li L, Bischler T, Barquist L, Reinhardt R, Backofen R, Vogel J. 2016. Global RNA recognition patterns of post-transcriptional regulators $\mathrm{Hfq}$ and $\mathrm{CsrA}$ revealed by UV crosslinking in vivo. EMBO J 35: 991-1011. doi:10.15252/embj .201593360

Holmqvist E, Li L, Bischler T, Barquist L, Vogel J. 2018. Global maps of ProQ binding in vivo reveal target recognition via RNA structure and stability control at mRNA $3^{\prime}$ ends. Mol Cell 70: 971-982. doi:10.1016/j.molcel.2018.04.017

Hör J, Gorski SA, Vogel J. 2018. Bacterial RNA biology on a genome scale. Mol Cell 70: 785-799. doi:10.1016/j.molcel.2017.12.023

Hör J, Garriss G, Di Giorgio S, Hack LM, Vanselow JT, Förstner KU, Schlosser A, Henriques-Normark B, Vogel J. 2020a. Grad-seq in a Gram-positive bacterium reveals exonucleolytic sRNA activation in competence control. EMBO J 39: e103852. doi:10.15252/embj .2019103852

Hör J, Di Giorgio S, Gerovac M, Venturini E, Förstner KU, Vogel J. 2020b. Grad-seq shines light on unrecognized RNA and protein complexes in the model bacterium Escherichia coli. Nucleic Acids Res. doi:10.1093/nar/gkaa676

Immer C, Hacker C, Wöhnert J. 2018. NMR resonance assignments for a ProQ homolog from Legionella pneumophila. Biomol NMR Assign 12: 319-322. doi:10.1007/s12104-018-9831-6

Kolb FA, Westhof E, Ehresmann B, Ehresmann C, Wagner EGH, Romby P. 2001. Four-way junctions in antisense RNA-mRNA complexes involved in plasmid replication control: a common theme? J Mol Biol 309: 605-614. doi:10.1006/jmbi.2001.4677

Lagier J-C, Khelaifia S, Alou MT, Ndongo S, Dione N, Hugon P, Caputo A, Cadoret F, Traore SI, Seck EH, et al. 2016. Culture of previously uncultured members of the human gut microbiota by culturomics. Nat Microbiol 1: 16203. doi:10.1038/nmicrobiol .2016 .203

Lee E-J, Groisman EA. 2012. Control of a Salmonella virulence locus by an ATP-sensing leader messenger RNA. Nature 486: 271277. doi:10.1038/nature11090

Li X, Sun Q, Jiang C, Yang K, Hung L-W, Zhang J, Sacchettini James C. 2015. Structure of ribosomal silencing factor bound to Mycobacterium tuberculosis ribosome. Structure 23: 1858-1865. doi:10.1016/j.str.2015.07.014

Lott SC, Schäfer RA, Mann M, Backofen R, Hess WR, Voß B, Georg J. 2018. GLASSgo - automated and reliable detection of sRNA homologs from a single input sequence. Front Genet 9: 124. doi:10.3389/fgene.2018.00124

Mallam AL, Sae-Lee W, Schaub JM, Tu F, Battenhouse A, Jang YJ, Kim J, Wallingford JB, Finkelstein IJ, Marcotte EM, et al. 2019. Systematic 
discovery of endogenous human ribonucleoprotein complexes. Cell Rep 29: 1351-1368. doi:10.1016/j.celrep.2019.09.060

Mark Glover JN, Chaulk SG, Edwards RA, Arthur D, Lu J, Frost LS. 2015. The FinO family of bacterial RNA chaperones. Plasmid 78: 79-87. doi:10.1016/j.plasmid.2014.07.003

Melamed SP, Faigenbaum-Romm A, Gatt YE R, Reiss N, Bar A, Altuvia Y, Argaman L, Margalit H. 2016. Global mapping of small RNA-target interactions in bacteria. Mol Cell 63: 884-897. doi:10.1016/j.molcel.2016.07.026

Melamed S, Adams PP, Zhang A, Zhang H, Storz G. 2020. RNA-RNA interactomes of $\mathrm{ProQ}$ and $\mathrm{Hfq}$ reveal overlapping and competing roles. Mol Cell 77: 411-425. doi:10.1016/j.molcel.2019.10.022

Michaux C, Holmqvist E, Vasicek E, Sharan M, Barquist L, Westermann AJ, Gunn JS, Vogel J. 2017. RNA target profiles direct the discovery of virulence functions for the cold-shock proteins CspC and CspE. Proc Natl Acad Sci 114: 6824-6829. doi:10.1073/pnas.1620772114

Olejniczak M, Storz G. 2017. ProQ/FinO-domain proteins: another ubiquitous family of RNA matchmakers? Mol Microbiol 104: 905-915. doi:10.1111/mmi.13679

Pagliuso A, Tham TN, Allemand E, Robertin S, Dupuy B, Bertrand Q, Bécavin C, Koutero M, Najburg V, Nahori M-A, et al. 2019. An RNA-binding protein secreted by a bacterial pathogen modulates RIG-I signaling. Cell Host Microbe 26: 823-835. doi:10.1016/j .chom.2019.10.004

Pandey S, Gravel CM, Stockert OM, Wang CD, Hegner CL, LeBlanc H, Berry KE. 2020. Genetic identification of the functional surface for RNA binding by Escherichia coli ProQ. Nucleic Acids Res 48: 4507-4520. doi:10.1093/nar/gkaa144

Panja S, Woodson SA. 2012. Hfq proximity and orientation controls RNA annealing. Nucleic Acids Res 40: 8690-8697. doi:10.1093/ nar/gks618

Perez-Riverol Y, Csordas A, Bai J, Bernal-Llinares M, Hewapathirana S, Kundu DJ, Inuganti A, Griss J, Mayer G, Eisenacher M, et al. 2018. The PRIDE database and related tools and resources in 2019: improving support for quantification data. Nucleic Acids Res 47: D442-D450. doi:10.1093/nar/gky1106

Persson C, Wagner EG, Nordström K. 1988. Control of replication of plasmid R1: kinetics of in vitro interaction between the antisense RNA, CopA, and its target, CopT. EMBO J 7: 3279-3288. doi:10 .1002/j.1460-2075.1988.tb03195.x

Pilla G, Tang CM. 2018. Going around in circles: virulence plasmids in enteric pathogens. Nat Rev Microbiol 16: 484-495. doi:10.1038/ s41579-018-0031-2

Queiroz RML, Smith T, Villanueva E, Marti-Solano M, Monti M, Pizzinga M, Mirea D-M, Ramakrishna M, Harvey RF, Dezi V, et al. 2019. Comprehensive identification of RNA-protein interactions in any organism using orthogonal organic phase separation (OOPS). Nat Biotechnol 37: 169-178. doi:10.1038/s41587-018-0001-2

Rae CD, Gordiyenko Y, Ramakrishnan V. 2019. How a circularized tmRNA moves through the ribosome. Science (New York, NY) 363: 740-744. doi:10.1126/science.aav9370

Robinson JT, Thorvaldsdóttir H, Winckler W, Guttman M, Lander ES, Getz G, Mesirov JP. 2011. Integrative genomics viewer. Nat Biotechnol 29: 24-26. doi:10.1038/nbt.1754

Schwanhäusser B, Busse D, Li N, Dittmar G, Schuchhardt J, Wolf J, Chen W, Selbach M. 2011. Global quantification of mammalian gene expression control. Nature 473: 337-342. doi:10.1038/ nature 10098

Sharan M, Förstner KU, Eulalio A, Vogel J. 2017. APRICOT: an integrated computational pipeline for the sequence-based identification and characterization of RNA-binding proteins. Nucleic Acids Res 45: e96. doi:10.1093/nar/gkx137
Shchepachev V, Bresson S, Spanos C, Petfalski E, Fischer L, Rappsilber J, Tollervey D. 2019. Defining the RNA interactome by total RNA-associated protein purification. Mol Sys Biol 15: e8689. doi:10.15252/msb.20188689

Smirnov A, Forstner KU, Holmqvist E, Otto A, Gunster R, Becher D, Reinhardt R, Vogel J. 2016. Grad-seq guides the discovery of ProQ as a major small RNA-binding protein. Proc Natl Acad Sci 113: 11591-11596. doi:10.1073/pnas.1609981113

Smith T, Villanueva E, Queiroz RML, Dawson CS, Elzek $M$, Urdaneta EC, Willis AE, Beckmann BM, Krijgsveld J, Lilley KS. 2020. Organic phase separation opens up new opportunities to interrogate the RNA-binding proteome. Curr Opin Chem Biol 54: 70-75. doi:10.1016/j.cbpa.2020.01.009

Soufi B, Krug K, Harst A, Macek B. 2015. Characterization of the E. coli proteome and its modifications during growth and ethanol stress. Front Microbiol 6: 103. doi:10.3389/fmicb.2015.00103

Stein EM, Kwiatkowska J, Basczok MM, Gravel CM, Berry Katherine E, Olejniczak M. 2020. Determinants of RNA recognition by the FinO domain of the Escherichia coli ProQ protein. Nucleic Acids Res gkaa497. doi:10.1093/nar/gkaa497

Tawk C, Sharan M, Eulalio A, Vogel J. 2017. A systematic analysis of the RNA-targeting potential of secreted bacterial effector proteins. Sci Rep 7: 9328. doi:10.1038/s41598-017-09527-0

Timmis KN, Andrés I, Achtman M. 1978. Fertility repression of F-like conjugative plasmids: physical mapping of the R6-5 finO and finP cistrons and identification of the finO protein. Proc Natl Acad Sci 75: 5836-5840.

Tomizawa J-i. 1990. Control of ColE1 plasmid replication: interaction of Rom protein with an unstable complex formed by RNA I and RNA II. J Mol Biol 212: 695-708. doi:10.1016/0022-2836(90) 90231-A

Trendel J, Schwarzl T, Horos R, Prakash A, Bateman A, Hentze MW, Krijgsveld J. 2019. The human RNA-binding proteome and its dynamics during translational arrest. Cell 176: 391-403. doi:10 .1016/j.cell.2018.11.004

The UniProt Consortium. 2018. UniProt: a worldwide hub of protein knowledge. Nucleic Acids Res 47: D506-D515.

Urdaneta EC, Vieira-Vieira CH, Hick T, Wessels H-H, Figini D, Moschall R, Medenbach J, Ohler U, Granneman S, Selbach M, et al. 2019. Purification of cross-linked RNA-protein complexes by phenol-toluol extraction. Nat Commun 10: 990. doi:10.1038/ s41467-019-08942-3

Walter P, Ibrahimi I, Blobel G. 1981. Translocation of proteins across the endoplasmic reticulum. I. Signal recognition protein (SRP) binds to in-vitro-assembled polysomes synthesizing secretory protein. J Cell Biol 91: 545-550. doi:10.1083/jcb.91.2.545

Wassarman KM, Storz G. 2000. 6S RNA regulates E. coli RNA polymerase activity. Cell 101: 613-623. doi:10.1016/S0092-8674(00) 80873-9

Weinberg Z, Breaker RR. 2011. R2R - software to speed the depiction of aesthetic consensus RNA secondary structures. BMC Bioinformatics 12: 1-9. doi:10.1186/1471-2105-12-3

Westermann AJ, Venturini E, Sellin ME, Förstner KU, Hardt W-D, Vogel J. 2019. The major RNA-binding protein ProQ impacts virulence gene expression in Salmonella enterica serovar Typhimurium. mBio 10: e02504-e02518. doi:10.1128/mBio.02504-18

Wiśniewski JR, Rakus D. 2014. Quantitative analysis of the Escherichia coli proteome. Data Brief 1: 7-11. doi:10.1016/j.dib.2014.08.004

Yao Z, Weinberg Z, Ruzzo WL. 2005. CMfinder-a covariance model based RNA motif finding algorithm. Bioinformatics 22: 445-452. doi:10.1093/bioinformatics/btk008

Zitomer RS, Flaks JG. 1972. Magnesium dependence and equilibrium of the Escherichia coli ribosomal subunit association. J Mol Biol 71: 263-279. doi:10.1016/0022-2836(72)90350-6 

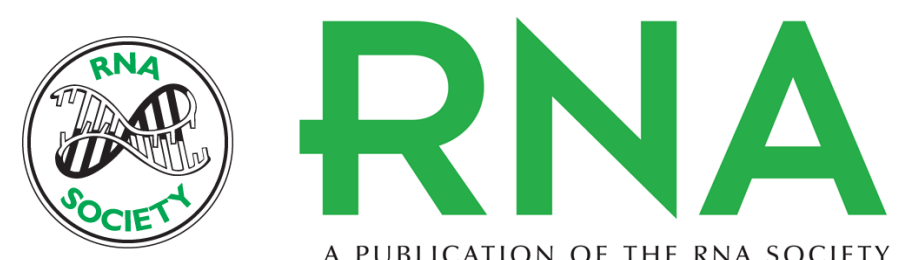

A PUBLICATION OF THE RNA SOCIETY

\section{Global discovery of bacterial RNA-binding proteins by RNase-sensitive gradient profiles reports a new FinO domain protein}

Milan Gerovac, Youssef El Mouali, Jochen Kuper, et al.

RNA 2020 26: 1448-1463 originally published online July 9, 2020

Access the most recent version at doi:10.1261/rna.076992.120

\section{Supplemental http://rnajournal.cshlp.org/content/suppl/2020/07/09/rna.076992.120.DC1 Material}

References This article cites 84 articles, 17 of which can be accessed free at: http://rnajournal.cshlp.org/content/26/10/1448.full.html\#ref-list-1

Open Access Freely available online through the RNA Open Access option.

Creative This article, published in RNA, is available undera Creative Commons License Commons (Attribution-NonCommercial 4.0 International), as described at License http://creativecommons.org/licenses/by-nc/4.0/.

Email Alerting Receive free email alerts when new articles cite this article - sign up in the box at the Service top right corner of the article or click here.

\section{|||||||| Providing Precise Solutions for your research.}

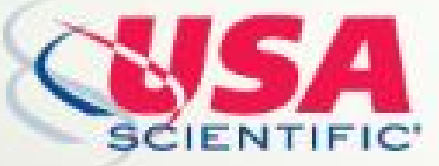

To subscribe to $R N A$ go to:

http://rnajournal.cshlp.org/subscriptions

(C) 2020 Gerovac et al.; Published by Cold Spring Harbor Laboratory Press for the RNA Society 